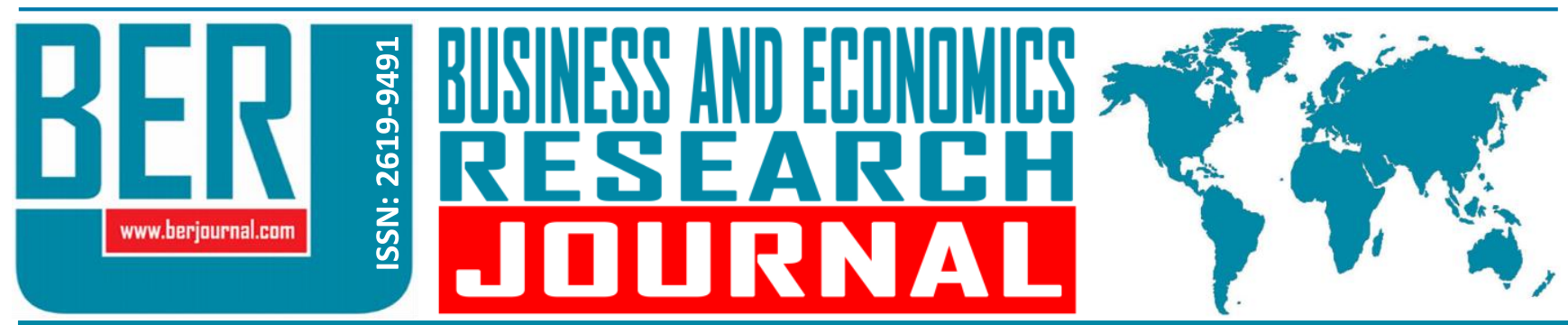

Business and Economics Research Journal Vol. 11, No. 4, 2020, pp. 1013-1033 doi: 10.20409/berj.2020.296

\section{Osmanlı İmalat Sanayisinde Sermayenin Kurumsallaşması Sorunsalı: Bursa İpek Sektörü Üzerine Bir Değerlendirme}

\author{
Ozgur Teoman $^{\mathrm{a}}$, Cumali Bozpinar ${ }^{\mathrm{b}}$
}

Öz: Osmanlı Imparatorluğu'nda kapitalizme geçiş tartışmaları güncelliğini korumaktadır. Bu çalışmada, kurumsal bir kredi mekanizmasının yokluğunda Osmanlı imparatorluğu'nda kurulu kapitalist ilişkilerin gelişebilmesinde sermayenin rolü şirketleşme pratiği üzerinden araştırılmıştır. Bunun için XIX. yüzyıl Bursa ipek sektörü örneğinden hareket edilmiştir. Bursa ipek sektörünün seçilmiş olmasının nedeni, Osmanlı Imparatorluğu'nun Avrupa piyasaları ile en fazla bütünleşmiş sektörü olmasıdır. Sektörün bu niteliği, Batı Avrupa ile Osmanlı Imparatorluğu'nu sanayi kapitalizmi yönünden karşılaştırmaya imkân sağlamıştır. Karşılaştırma yapabilmek için Batı Avrupa şirketleşme tarihi, ikincil kaynaklar ve konu üzerine yapılan çalışmalar incelenmiştir. Bu kapsamda, Osmanlı Imparatorluğu'nda kurumsal organizasyonların ortaya çıkışı ve gelişmesinde etkili olan siyasi, dini ve sosyokültürel özellikler göz önünde bulundurulmuştur. Söz konusu özelliklere bağlı olarak, Batı Avrupa'daki şirketleșmeden farklı bir biçimde, ham madde-ara mal üretimi noktasında da olsa Bursa ipek sektöründe kapitalist dönüşümün sarraf-yabancı/azınlık tüccar-bürokrat iş birliğinin resmi ve zımni anlaşmaları yoluyla gerçekleştiği anlaşılmıştır. Ancak kapitalist dönüşüm nihai-mamul mal (ipekli dokuma) ile diğer tekstil imalatında gözlenmeyip, Ingiltere ile imzalanan 1838 Balta Limanı Anlaşması'yla birlikte Imparatorluğun merkezçevre iliskisine tam olarak eklemlenmesi sonucunda bu faaliyet kollarında istihdam ve üretim kaybı yaşanmıştır.

\section{The Problem of Institutionalization of Capital in the Ottoman Manufacturing Industry: An Evaluation on Bursa Silk Sector}

Abstract: The debate on transition to capitalism in the Ottoman Empire continues. In this study, the role of capital in the development of capitalist relations in the Ottoman Empire in the absence of an institutional credit mechanism was investigated through the incorporation practice. For this purpose, the XIXth century Bursa silk sector case was analysed. This is because it is the most integrated among the Ottoman Empire sectors with the European markets. This quality of the sector has enabled the comparison of Western Europe with the Ottoman Empire in terms of industrial capitalism. For making the comparison, Western European company history, secondary sources and studies on the subject were examined. In this context, the political, religious, and socioeconomic features that were effective on the emergence and development of institutional organizations in the Ottoman Empire were taken into consideration. Depending on the characteristics in question, it was understood that the capitalist transformation was realized through formal and tacit agreements of usurer-foreign/minority merchant-bureaucrat cooperation in Bursa silk sector, differently from the corporation in Western Europe, even at the point of raw material-intermediate production. However, the capitalist transformation was not observed in the manufacture of final products and other textiles, and that then loss of employment and production appeared in these branches of activity as a result of the complete incorporation of the Empire into the center-periphery relationship with the Act of Port of Treaty of 1838 signed with Britain.
Anahtar Sözcükler: Şirketleşme, Bursa, İpek, Sarraf, Sanayisizleşme

JEL: N65, N95

$\begin{array}{ll}\text { Geliş } & : 22 \text { Mayıs } 2020 \\ \text { Düzeltme } & : \text { 21 Temmuz } 2020 \\ \text { Kabul } & : \text { 03 Eylül 2020 } \\ \text { Tür } & : \text { Araştırma }\end{array}$

Keywords: Corporatization, Bursa, Silk, Usurer, Deindustrialization

JEL: N65, N95
Received : 22 May 2020

Revised : 21 July 2020

Accepted : 03 September 2020

Type : Research

a Assoc. Prof., PhD., Hacettepe University, Department of Economics, Ankara, Turkiye, ozgurt@hacettepe.edu.tr (ORCID ID: 0000 0002-2237-042X)

b PhD., Ministry of Environment and Urbanism (General Directorate of National Estate), Ankara, Turkiye, cumalispontik@gmail.com (ORCID ID: 0000-0001-8760-5253) 


\section{Giriş}

Batı Avrupa'da ticaret ve sanayi kapitalizminin gelişmesinde sermaye ortaklıkları önemli rol oynamıştır. Osmanlı İmparatorluğu'nda ise ortaklık formundaki organizasyonlar böylesi bir niteliğe sahip olamamışır. Çünkü gerek İslam hukukunun piyasa aktörleri bakımından kolektif oluşumlar yerine bireysel girişimleri önceleyen hükümleri gerekse loncaların zanaat üretimini kendi üyeleri haricindeki sermaye sahiplerine kapatan geleneksel kuralları, sermayenin Müslüman tebaa arasındaki ortaklıklar vasıtasıyla üretim ve mübadele sürecine nüfuz edebilmesini sınırlandırmıştır. Nitekim XVIII. yüzyıla kadar ortaklıklar, ağırlıklı olarak yabancı tüccarların ülkenin iç ve dış ticaretinde çeşitli faaliyetleri gerçekleştirmek ve bu faaliyetlerle ilgili ticari riski paylaşmak amacıyla kurulmuştur. Sanayi Devrimi'nin dünya ekonomik düzeninde üretim ve mübadele ilişkileri bakımından meydana getirdiği dönüşüm, Osmanlı İmparatorluğu'nda da 1839 Tanzimat Fermanı'nın (Gülhane Hatt-ı Şerifi, Gülhane Hatt-ı Hümâyûnu) ilanı sonrasında sanayileşmeye dönük farkındalığı ve çabaları artırmış ve hukuksal açıdan Batı mevzuatına uygun şirketleşme olgusu yasal ve kurumsal düzeyde gündeme gelmiştir. Fermanın Osmanlı tebaasını oluşturan topluluklar arasında getirdiği eşitlikçi anlayışın mülkiyet düzleminde kabulünün sermaye ortaklıklarını teşvik ederek sanayileşmeye yönelik girişimlerin önünü açacağı beklentisine yol açmışsa da 1838 Osmanlı-İngiliz Serbest Ticaret Anlaşması (Balta Limanı Anlaşması) hükümlerinin yürürlüğe girmesi beklenilenin tersine bir eğilimle dokumacılık başta olmak üzere zanaata dayalı imalatlarda üretim ve istihdam bakımından gerilemeye yol açmıştır. Zanaata dayalı imalatlarda ortaya çıkan sanayisizleşme olgusu, İmparatorluğun kuruluşundan itibaren iç ve dış ticarete dönük uzmanlaşmanın giderek artıp ileri düzeye geldiği ipekli dokuma sektöründe de yaşanmıştır. Bununla birlikte Osmanlı ipekli sektörünün merkezi konumunda olan Bursa'da değişik üretim biçimlerinin bir arada bulunması olanağından yararlanan tüccar sermayesi, ham ipek ve ipek ipliği üretiminde loncalar dışında üretim sürecini örgütleyebilmiş ve ipekli dokuma imalatının tersine Fransa merkezli dış talebi karşılamaya yönelik ücretli iş gücü ve mekanizasyona geçişi sağlayabilmiştir. Mekanizasyona dayalı iplik üretim (filatür) tesislerinin kurulmasında sarraf-azınlık/yabancı tüccar-bürokrat resmi ve zımni sermaye ortaklıkları Avrupa deneyimlerine benzer biçimde önemli rol oynamıştır.

Bu çalışmada sermaye ortaklıklarının imalat üretimindeki kapitalist üretim ilişkilerine geçişteki işlevi XIX. yüzyıldaki Bursa ipekli sektörü özelinde incelenmiştir. Çalışma dört bölümden oluşmaktadır. Girişi takip eden ilk bölümde sermaye ortaklıklarının ve şirketleşmenin gelişimi tarihsel perspektiften ele alınmaktadır. Çalışmanın ikinci bölümü Osmanlı İmparatorluğu'nda borçlanma ve kredi ilişkilerini ikame etmeye dönük mekanizmaların açıklanması üzerine odaklanmaktadır. Üçüncü bölümde ise XIX. yüzyıl Bursa'sında ipek ipliği üretiminde sanayi kapitalizmine geçiş süreci incelenmekte ve çalışma, elde edilen bulgulara ilişkin değerlendirmelerde bulunularak sonlandırılmaktadır.

\section{Sermaye Ortaklıklarının ve Şirketleşmenin Tarihsel Geçmişine Kurumsal iktisat Merkezli Bakış}

Ana akım iktisat uyarınca kurumlar piyasa ilişkilerini düzenlemek yoluyla iktisadi karar birimlerinin yaşamlarına katkıda bulunan hukuki organizasyonlar biçiminde tanımlanmaktadır. Kurumsal iktisat ${ }^{1}$ yazınında ise kurum terimi, kelime anlamının çağrıştırdığı yasal organizasyon biçiminde değil, daha çok geçmişten köklenen ve insan topluluklarını geleceğe taşıyan istikrarlı davranış tarzlarını ve düşünce alışkanlıklarını ifade etmekte ve kavramsal olarak terimin sosyolojik boyutu ön plana çıkmaktadır (Genç ve Ekiz, 2017). Sermaye ortaklıkları ve şirketlerin kuruluş ve gelişmeleri bu yaklaşım uyarınca tarihsel perspektiften değerlendirildiğinde, kurumsal yapı olarak sadece piyasa merkezli bir analizin yeterli olmayıp bu yapıların siyasi, sosyokültürel ve teknolojik açıdan desteklenerek bütüncül bir analiz yapılması gereği ortaya çıkmaktadır. Bu çalışmanın temel konusunu şirketleşme olgusunun tarihsel süreçteki etkilerinin analizi oluşturduğundan, çalışmada neoklasik iktisadın rasyonel birey merkezli rekabetçi piyasa ve tam bilgi varsayımlarına dayalı tekil karar birimi temelli analizi yerine kurumsal iktisadın benimsediği bütüncül analizin daha uygun yöntem olacağı düşünülmüştür.

Kurumsal iktisadi yaklaşım uyarınca kurumlar, insanlar arasındaki ilişkileri belirleyen insanlar tarafından yaratılmış kurallar ve kısıtlamalar bütünü olarak görüldüğünden (Seçilmiş, 2016: 13) söz konusu kural ve kısıtlamaların insanlar tarafından nasıl belirlendiğinin tespiti önem taşımaktadır. Kural ve kısıtlamaların belirlenmesindeki iktisadi motivasyon insan rasyonalitesine bağlı olup rasyonalite ise kurumsal 
iktisat uyarınca toplumsal ve kültürel çerçevede belirlenerek birey alışkanlıkları, gelenekleri ve güdüleri ile koşullanırlar (Genç ve Ekiz, 2017). Her ne kadar karar alıcı birey "homo economicus" varsayımı gereği davranış ve tercihlerini karar almanın ayrıştırılmış doğasına göre belirliyor olsa da içerisinde bulunduğu ekonomik ve sosyal örgütlenme biçimlerinde faaliyette bulunabilmesi çeşitli kurumlara ihtiyaç gösterir (Shearmur, 1996: 118-26). Tarihsel süreçte kurumların ortaya çıkışı iki temel koşul uyarınca incelenmektedir. Bunlardan ilkinde kurumun ortaya çıkışı bilinçli-iradi düzenlenen bir yapının unsuru olarak gerçekleşirken diğer alternatifte kurum önceden planlanmamış bir biçimde toplumsal olarak sosyoekonomik koşullardaki değişime bağlı olarak intiyaca binaen ortaya çıkmaktadır. Illk durumda yani iradi düzenlemelerde siyasi olarak iktidarı ellerinde bulunduranlar belirli bir amaca ulaşabilmek için kurallar koyarak kurumların kuruluşunu organize ederler. Bir ihtiyaç hasıl olduğunda kurumların ortaya çıkışı ise çok daha karmaşık, devlet benzeri belirli bir düzenleyenin olmadığı, organizasyonun kendiliğinden oluştuğu bir yapıdır. Bu yolla meydana gelen kurumsal yapı önceden belirlenmiş ve kesin bir amaca dönük olarak kurgulanmadığı için birçok iktisadi ve hukuki belirsizliği de içinde barındııır (Hayek, 1998: 46-54). Başlangıçta mübadele ilişkilerinin yerel (lokal) düzeyde yürütüldügü iktisadi koşullarda maneviyata dayalı normlar ve kurallar geçerli iken taşımacılık ve ulaştırma olanaklarının gelişmesiyle uzak mesafeli ticaretin artması sonucu piyasadaki işlemlerin tamamen fiyatlar tarafından koordine edildiği genişletilmiş piyasa düzenine geçilir. Genişletilmiş piyasa düzeninde ise mübadeleye taraf olanlar arasındaki sözleşmelere dayalı düzenlemeler manevi (ahlâki) iktisadi değer yargılarının doğal kısıtlarından arınır ve piyasa rasyonalitesi baskın hale gelir (Shearmur, 1996: 118).

Sermayenin kurumsal formda organize oluşunun geçmişi iktisadi olarak tarım toplumlarının egemen olduğu dönemlere dek gitmektedir. Antik Çağ'da servetin temel kaynağı olan ticari faaliyet, Fenikeliler ve Kartacalılar gibi tüccar halkların sermaye birikimlerini çoğaltmaya dönük organize olmalarıyla gelişme göstermiştir (Marx, 2011: 267). Yukarıda belirtildiği gibi taşımacılık ve ulaştırma olanaklarının artmasına paralel olarak gelişen medeniyetler arasındaki ticari ilişkiler, ticari riskin ve kârın finanse edenler ile tüccarlar arasında ortak katılım yoluyla paylaşılması fikrini beraberinde getirmiştir. Nitekim önce Antik Yunan ve Roma'da, ardından italyan şehir devletlerinde zengin asiller ticari seferlere çıkan gemi sahipleri ile anlaşıp başlangıçtaki harcama ve masraflara katkıda bulunarak bu katkıdan hisseleri doğrultusunda pay almışlardır. Anonim ticaret şirketlerinin embriyonik biçimi olarak kabul edilebilecek "commenda" ${ }^{2}$ ise XIII. ve XIV. yüzyıllarda dış ticaretin yaygın olduğu İtalyan şehir devletlerinde sermaye sahiplerinin sermayelerini tüccarlara ticari faaliyette kullandırarak artırabilmesine, tüccarın ise ticaret yapabilmesi için ihtiyaç duyduğu sermaye kısıtını aşmasına olanak sağlayabilmek amacıyla geliştirilmiştir. Buna göre "contratto dicommenda" adı verilen bir ortaklık senedi üzerinden yapılan ortaklılarda ortaklardan bazıları sermayeyi temin ederken diğerlerinin yatırımları yönettiği görülmektedir (Walker, 1931: 97). Başlangıçta, kurulan ortaklıklarda yakın akrabaların mevcut kaynaklarını ortak bir havuzda toplayıp ticari bir işletme oluşturmalarını sağlama amacı güdülmüştür. Kapitalizm öncesi sosyoekonomik yapıların ortak özelliğinin yansıması olarak iktisat dışı bir faktör olan güven esasına dayalı ${ }^{3}$ bu tip ortaklıklarda paydaşlar birbirleri hakkında yoğun ve kişisel düzeyde bilgi sahibidirler (Kama, 2011: 198). Bu ortaklıkların en büyük sorunu, tüm ortakların müşterek ve sınırsız olarak diğer ortakların da borçlarından sorumlu olmalarını kısıtlayabilecek bir mekanizmanın bulunmayışı olmuştur. Bu sorunu giderebilmek amacıyla Roma İmparatorluğu'nda hukukçular farklı kesimlerin bir araya gelmesiyle oluşan ortaklık organizasyonunun hukuki alt yapısı için gerekli olan bireysel üyelerden bağımsız hak ve yükümlülükleri tanımlayıcı "tüzel kişilik" kavramını geliştirmişler ve kavramı "societas" terimiyle ifade etmişlerdir (Hadden, 1972: 5-8). Böylece hukuki alt yapısı oluşturulan anonim şirketlerin gelişmesinin diğer şirket türlerinden ayırıcı özelliği, kâr elde eden bir şirketle doğrudan bağlantısı olmayan kişilere (hissedarlar) sermayelerini büyük çapta büyütebilme olanağını sağlaması olmuştur. Öte yandan bu kişiler bundan böyle günümüzdeki noter benzeri bir müessese nezdinde imzaladıkları bir poliçe ile (ticari geminin batması, korsanlarca ele geçirilmesi $v b$.) olası bir zarar durumunda bu riskin sınırsız paylaşımı yükümlülüğünden kurtulmuşlardır (Cipolla, 2005: 127).

Batı Avrupa'da ticari şirketlerin gelişmesi XVI. yüzyılın başında coğrafi keşiflerle birlikte artan uzun mesafeli ticaret ile birlikte hız kazanmıştır. Zira uzun mesafeli ticaretin artması sermayeye olan ihtiyacı artırmış, keşiflerden önce şirket ortaklarının sermayeleri nispetinde sınırlı sorumlu olmaları durumu değişikliğe uğramıştır. Bu nedenle coğrafi keşifler, ticari ortaklığa yönelmede kurumsal ifadesini bulan şirketleşme bakımından bir dönüm noktası olarak kabul edilebilir. Coğrafi keşiflerin yükselişi, merkantilist 
görüş uyarınca kavramsal olarak servet anlayışında da önemli bir değişikliği beraberinde getirmiş ve devletlerin maddi gücü ülkeye değerli maden akışını sağlayacak olan ihracatın artırılmasına bağlı hale gelmiştir. Coğrafi keşiflerin yanı sıra Batı Avrupa'da gerçekleşen Reformasyon hareketlerinin sermaye sahiplerini kilisenin egemenliğinden kurtararak birikimlerini şirketlere borç vererek kullandırmalarında rol oynayan önemli bir diğer faktör olmuştur (Walker, 1931: 99).

Ulus devletlerin maddi gücünün kaynağını teşkil eden ticari kapitalizmin gelişmesi, ticari faaliyetlerin kurumsal ve hukuki yapısında bir dönüşümü beraberinde getirmiştir. Buna göre kurumların ortaya çıkışı hususunda belirtildiği gibi merkezi otorite yasal düzenlemeleri yaparak ticari faaliyetin imtiyazını bir kontrat aracılığıyla özel bölgelere hasreden ticari korporasyonlara (kumpanyalara) bahşetmeye başlamıştır. Böylece devlet farklı biçimlerde de olsa, vergi ve ucuz kredi aracılığıyla imtiyaz verdiği şirketlerin kârlarından pay alarak kendi adına merkantilist kaynak aktarım mekanizmasını harekete geçirebilmiştir (Kuran, 2018: 153). Ingiltere'de henüz 1407 'de Kral IV. Henry'nin imtiyaznamesi ile kurulmuş olan Company of Merchant Adventurers of London (Londra Ticaret Maceraperestleri Şirketi) başlangıçta Hollanda gibi yakın ülkelerle, daha sonra ise Alman Hansa Ligi şehirleriyle ve Danimarka, Norveç ve İsveç gibi daha uzak ülkelerle ticaret yapmıştır. Şirket kısa sürede hızla büyüyerek İngiliz ticaretinin büyük bölümünü, ağırlığı kıtadaki fuarlara taşınmak üzere Anvers'e gönderilmek üzere yünlü ürün ticareti olmak üzere, kontrol etmeye başlamıştır. XVI. yüzyılın ortasında İngiltere'de denizaşırı ticaret yapmak isteyen yeni girişimciler ortaya çıkmıştır. İlk kayda değer girişim Mysteryand Company of Merchant Adventurers to the New Lands and Places Unknown (Keşfedilmemiş Yeni Bölge ve Topraklara Ticari Maceraperestler Şirketi) olmuştur (Yülek, 2019: 50). Dış ticarette güney güzergâhlara rakip ülkeler hâkim olduğundan kuzeyden yeni yollar açarak Çin'e ulaşmayı hedefleyen bu şirket, daha sonra kurulacak olan The English East India Company (Ingiliz Doğu Hindistan Şirketi)'nin de aralarında bulunduğu diğer merkantilist şirketlere örnek olmuştur. Söz konusu deneyimlerin ardından Hollanda ile birlikte "anonim şirket" adı altında yeni bir işletme modeli geliştiren iki ülkeden biri İngiltere olmuştur. 1553'te İngiltere'de kurulan Russian Company (Muscovy Company) (Rus Şirketi) ve Royal African Company (Afrika Kraliyet Şirketi) ilk önemli anonim şirketler olarak kabul edilmektedir (Walker, 1931: 99).

Anonim şirketler olarak örgütlenen merkantilist nitelikteki İngiliz ve Hollandalı şirketleri, şirket bazında kurumsallaşmanın yeni bir türü olarak önemli ekonomik sonuçlar ortaya çıkarmışırı. İlk olarak çok sayıda sermaye sahibi yatırımcı ellerindeki sermayeyi bu sermayeden yoksun girişimci ve yöneticiye kullandırmak suretiyle ticari işletmelerin kurulmasına ve işletilmesine katkıda bulunma olanağına sahip olmuşlardır (Yülek, 2019: 22). Bu gelişme öncelikle kolonilerin kuruluşundaki masrafların devlet hazineleri tarafından finanse edilmesi intiyacını ortadan kaldırmıştır. Ardından anonim şirketler kapılarını birçok hissedara açıp sermaye havuzu oluşturarak riski dağıtmışlar ve böylece özel tasarruflar kâr amaçlı girişimci sömürgeci şirketlere yönlendirilebilmiştir. 1622'de parlamentoda kabul edilen bir yasa ile Doğu Hindistan, Afrika ve Balıkçıık Şirketleri hissedarlarının şirketlerin karşılaşabilecekleri olası bir iflas durumunda iflas yasasına tabi olmamaları, dolayısıyla sınırlı sorumluluğa sahip olmaları koşulu kabul edilmiştir (Walker, 1931: 103). 1671 'de İngiltere'de Lordlar Kamarası'nda hissedarlar üzerine ticari yükümlülükler konulmasını öngören yasanın kabul etmesinin ardından yapılan düzenlemelerle hissedarlar açısından hisselerin devri şartsız bir hale gelmiştir. Böylece finansal pay ortağı yatırımcı günümüz modern ekonomilerinde olduğu şekliyle dava konusu olmaksızın hisselerini satıp şirketten çekilme hakkına sahip olmuştur. Bu düzenlemenin ardından anonim şirketlerin kuruluşlarını sağlayan bazı imtiyaznamelerin yayınlanmasıyla İngiliz anonim şirketlerinin yeni topraklarda yerleşimler kurulmasının önü açılmış, imtiyazı alan şirket, kendisine verilen topraklarda İngiltere ile ticaret dâhil tüm ekonomik faaliyetler için tekel hakları ${ }^{4}$ elde etmiştir. Böylece İngiliz sermaye sahiplerine sömürgelerden tekelci kârları sürekli kılarak transfer edebilmelerinin yolu açılmıştır (Yülek, 2019: 56).

Sıralanan tüm bu gelişmelerden, Batı Avrupa'da Sanayi Devrimi öncesinde ortaklık ve korporasyonların sermaye faktörünün henüz üretim biçimlerinin egemen unsuru olmadığı dönemlerde ortaya çıktığı, coğrafi keşifler ve Reformasyon hareketleri ile yüksek bir ivme kazanarak verilen imtiyazlar sonucunda tekelci bir nitelik kazandığı anlaşılmaktadır. Genel olarak değerlendirildiğinde, Batı Avrupa'daki söz konusu kurumsal gelişme sürecinin başarısını Batı Avrupa miras hukukunun işbirliğini kolaylaştırıcı niteliği 
ile siyasi otoritenin iktisadi karar süreçlerinde sermaye sahiplerini teşvik edici uygulamaları ile ilişkilendirmek mümkündür ${ }^{5}$.

Coğrafi keşiflerin ve Reformasyon hareketlerinin uyardığı şirketleşme olgusu, Batı Avrupa'da zanaat Ioncalarının çözülmeye başlaması ile bazı tüccar-zanaatkârların önce eve iş verme (putting-out) ve ardından manüfaktür üretim sistemine geçmeleri sonucunda ortaya çıkan üretimdeki kapitalist dönüşümle yeni bir boyut kazanmıştır. Sanayi kapitalizmine geçiş süreci sanayi kapitalistleri için sermaye birikimindeki artışların sürekli hale gelebilmesi bakımından sermaye temerküzünün ortaklıklar yoluyla sağlanması olanağını doğurmuştur. Ticari kapitalizmdeki şirketleşmedeki sermayenin kullanımından farklı biçimde sermaye ortaklığına dayalı şirketler bundan böyle para-ticaret-sanayi kapitalisti ayrımına uygun biçimde ${ }^{6}$ sanayici kapitalist tarafından ödünç alınan parasal sermayenin üretim araçlarında içerilmesiyle üretim sürecinde doğrudan bir işleve sahip olmuşlardır. Öte yandan Sanayi Devrimi'nin gelişim sürecinde, korporasyon kurumu özellikle iktisadi etkinlik açısından binlerce işçinin eşgüdümlü olarak yoğun sermaye kullanmasını gerektiren sektörlerde ${ }^{7}$ önemli yarar sağlamıştır. Buna göre korporasyon kurumu döner sermayeyi tekil hissedarlardan ve alacaklılarından korumaya dönük önlemler aracılığıyla sermaye birikimini desteklemiş, kurumsal varlıkları yağmalamak yerine kurumsal kazançlardan pay almayı teşvik ederek hissedar risklerini ise azaltmıştır. Böylece ticari korporasyon sanayi kapitalizminin hem finansmanına hem de işletme yönetimine katkıda bulunmuştur (Kuran, 2018: 155).

İngiltere'de sanayi kapitalizmine geçişle birlikte anonim şirketlerin sayısı artmasına karşın ${ }^{8}$ şahıs şirketi, adi ortaklık gibi basit şirket türleri revaçta kalmıştır (Kuran, 2018: 155). Bu duruma yol açan etken XVIII. yüzyılın başında yaşanan spekülatif finansal krizdir (South Sea Bubble). Finansal krizin ardından 1720'de imzalanan Bubble Act ile anonim şirketlerin parlamentodan yetki belgesi almadan kurulmaları yasaklanmıştır. Bu nedenle Sanayi Devrimi'nin temelini oluşturan imalatçı firmaların sermayelerini artırabilmek amacıyla kurmuş oldukları ortaklıklar, çoğunlukla basit ortaklıklar olarak nitelenmiştir (Neal ve Cameron, 2016: 174-5). Bu durum XIX. yüzyılın ortalarına kadar sürmüş ve 1844'te "katlı sorumluluk" ve ardından 1855'te "sorumsuzluk" kabul edilmiştir. Böylece yüzyılın ortasında şirket kurulmasına dair kurallar yeniden esnek hale getirilmiş ve finansal piyasaların işleyişi bakımından sermaye tabana yayılabilir hale gelmiştir. Bu yüzyıldaki kilit değişim ise "özgür korporatifleşme" nin yani herhangi bir idarenin ya da otoritenin onayı olmaksızın isteğe bağlı olarak tüzel kişilik kazanma hakkının tanınması olmuştur (Kuran, 2018: 156).

Diğer taraftan artan kârlarını hem finansal hem reel yatırımlar şeklinde dış piyasalarda değerlendirmeye yönelen Avrupalı bazı şirketler XIX. yüzyılda dünya ekonomisi açısından yeni bir dinamik süreci harekete geçirmişlerdir. Buna göre XIX. yüzyılda modern dünya ekonomik sisteminin bir yansıması olarak ortaya çıkan merkez-çevre ilişkisi ${ }^{9}$ bağlamında uluslararası iş bölümüne eklemlenen pek çok firma giriştikleri finansal ve reel yatırımlarla çevreden emperyalist nitelikte kaynak aktarımına yönelmişlerdir. Şirketler bir yandan demiryollarının yapımı başta olmak üzere alt yapı yatırımlarından elde ettikleri kârları, diğer yandan çevre ülkelerce istikraz edilen tahvillerden sağladıkları kazançlar ile sermaye birikimlerini artırmış ve çevreye dâhil ülkeleri kendilerine bağımlı kılmışlardır. Söz konusu bağımlılık ilişkisinin çevre bakımından önemli iktisadi sonucu ise aralarında Osmanlı İmparatorluğu'nun de bulunduğu birçok ülkede el emeğine dayalı zanaatların önemli bir kısmının artan ithal malları rekabeti karşısında yok olması, ayakta kalabilenlerde ise üretim ve istihdam bakımından bir gerileme sürecinin yaşanması olmuştur (Quataert, 2011).

\section{Osmanlı İmparatorluğu'nda Kredi ve Ortaklık Iilişkileri Üzerine}

Kapitalizm öncesi sosyoekonomik yapının bir karakteristiği olarak değerlendirilebilecek zihniyet ilkelerinden ${ }^{10}$ kaynaklı olarak piyasa ilişkilerinin XVII. yüzyıla gelinceye değin yeterince gelişmediği Osmanlı Imparatorluğu'nda iktisadi anlamda bireysel rasyonalite Batı Avrupa insanından oldukça farklı biçimlenmiştir. Buna göre bireysel düzeyde iktisadi kararların alınması ve eyleme geçirilmesinde Weberyan anlamda özsel rasyonelliğin ${ }^{11}$ (Weber, 2012: 199-201) baskın olduğu zihniyet yapısının bir unsuru olarak İslami hükümlerin Müslüman tebaanın iktisadi karar alma süreçleri üzerinde oldukça etkili olduğu görülmektedir. Nitekim İslami kurallar gereği faizin yasak oluşu, mübadele ilişkilerinde kredi mekanizmasının işleyişi önünde önemli bir engel oluşturmuştur. Bu önemli engele karşın piyasa ilişkilerinin görece gelişmiş olduğu şehirlerdeki üretici 
ve tüccarların bir bölümü ihtiyaç duydukları sermayeyi değişik borçlanma iliş̧ileri üzerinden sağlayabilmişlerdir. Bu kapsamda imparatorluğun genişleme döneminden itibaren Osmanlı şehirlerinde Batı Avrupa'daki gibi faiz üzerinden olmayan ancak kredi-faiz ilişkisini ikame edebilecek bazı iktisadi mekanizmaların "kâr payı" adı altında borçlanma ilişkilerinin gerçekleştirilmesinde araç olarak kullanıldığı görülmektedir ${ }^{12}$.

Faizin yasak oluşu doğal olarak kredi mekanizmasının resmi olarak kabul edilmiş kurumsal bir yapı üzerinden işlemesini zorlaştırmış ve Batı Avrupa'da olduğu gibi banka benzeri borç verebilen kurumların oluşumunun önünü tıkamıştır. Bu durumda Müslüman üretici-esnaf-tüccarın ihtiyaç duyduğu krediyi "para vakıfları" üzerinden temin etmeleri, sermaye temininde yaygın bir yöntem olarak uygulanmıştır.

Birçok İslam toplumunda olduğu gibi Osmanlı toplumunda da vakıflar, toplumsal dayanışma ilkesi gereğince maddi ve manevi anlamda yardıma ihtiyacı olan kesimlere katkı sağlamayı amaçlayarak kurulmuştur. Dolayısıyla vakıfların kuruluş ve işleyiş mantığının gerisinde dini bazı hüküm ve teamüllere uygun biçimde servetin (zenginliğin) ihtiyaç sahipleriyle paylaşılması ve yardımlaşma düşüncesi yer etmiştir. Öte yandan toplumdaki diğer zenginler gibi bazı esnaf ve tüccarların taşınmazlarını vakfedilmek üzere bağışlama eğilimlerinin gerisinde özel mülkiyet haklarının güvence sınıının belirsizliğine bağlı olarak devletin müsadere tehdidi de önemli bir motivasyon unsuru olarak yer almıştır (Kuran, 2018: 164-5). Hukuki olarak vakıflar yardımda/bağışta bulunanın geri döndürülemez biçimde bağışta bulunduğu maddi değerin vakfa transfer edilmesine dayanması nedeniyle bağışta bulunanın hür iradesiyle gerçekleştirdiği transfer sonucunda mülkiyet hakkı adeta vakıf üzerine hapsolunmuştur. Başlangıçta yardım amaçlı arazi, bina gibi taşınmazların bağışlanması uygulamasının yaygın olması sebebiyle vakıflara mülkiyet transferi ağılıklı olarak yukarıda belirtildiği gibi taşınmazlar üzerinden gerçekleşmiştir. XV. yüzyılın sonundan itibaren piyasa ilişkilerinin gelişmesi nakde olan ihtiyacı artırınca birtakım kişilerin yeddi-emin aracılığıyla paralarını kurmuş oldukları vakıflar üzerinden borç olarak kullandırdıkları bir sürece girilmiştir ${ }^{13}$. Borç olarak kullandırılan meblağa ilişkin vade sonunda yapılan ödeme başlangıçta irad, ardından murabaha adıyla vakfa kazanç olarak kaydedilmiş ve yardım ve hayır amaçı harcamaların finansmanında kullanılmıştır. Çizakça (2004) Bursa vilayeti geneli için yapmış olduğu çalışmasında bazı para vakıflarında vade sonunda vakfa geri dönen miktarın önemli dalgalanmalar göstermeyerek sabit bir geri dönüş oranına sahip olduğuna işaret etmektedir. Buradan söz konusu para vakıflarınca borç verilen murabahanın vakıf sahiplerinin üst sınıllarını belirlediği bir faiz haddi üzerinden ${ }^{14}$ işletilerek borç alanlara işletme sermayelerini artırma olanağı sağladığı sonucu çıkmaktadır.

Osmanlı İmparatorluğu'nda kurumsal bir kredi piyasasının yokluğunda üretim ve ticaret amacıyla sermaye temininde bir diğer alternatif ise sarraflar olmuştur. Başta i̇stanbul olmak üzere ticari ilişkilerin gelişmiş olduğu birçok vilayette ticaret yapan toplumsal kesimin önemli kısmının gayrimüslim tebaadan oluşması, bu kişileri ticari işletmelerinin kredi ve finansman ihtiyacının karşılanmasında sarraflara yöneltmiştir. Faizin yasak olması sebebiyle başlangıcından itibaren ülkedeki gayrimüslim tebaa tarafından yapılan ve önceleri Yahudilerin hâkimiyetinde olan sarraflık, Darphane emini Yaco Bonfil'in 1758 yılında Padişah III. Mustafa tarafından görevinden azledilip yerine Ermeni Mikail Düzyan'ın getirilmesinin ardından imparatorluğun yıkılışına kadar Ermeni tebaanın kontrolünde yürütülmüştür (Özsu, 2018: 27). XVII. yüzyılın sonunda ekonomide giderek artan rollerine bağlı olarak bir lonca çatısı altında örgütlenen sarraflar bundan böyle kurumsal bir kimlik kazanmışlardır. Sarraflar XVIII. yüzyıldan itibaren gerek iç ticarette loncaların kredi ihtiyacının karşılanmasındaki gerekse imparatorluğun vergi gelirlerinin transferindeki kritik rolleri sebebiyle merkezi otorite tarafından da itibar gören kişiler haline gelmişlerdir (Daşdemir, 1999: 476) ${ }^{15}$.

Tüm bu bilgilerden Osmanlı İmparatorluğu'nda faizin meşru olmadığı koşulda ve kurumsal bir kredi piyasasının yokluğunda borçlanma ilişkilerinde girişimci Müslüman tebaa açısından para vakıflarının, gayrimüslim tebaa açısından ise sarrafların birer aracı kurum olarak ön plana çıkmış oldukları anlaşılmaktadır.

Osmanlı İmparatorluğu'nda şirket benzeri kurumlar ise esas itibarıyla XIX. yüzyıldaki sanayileşme çaba ve girişimleri kapsamında gündeme gelmiş olmakla birlikte genişleme döneminden itibaren kayıtlarda sermaye ortaklıklarının izlerine rastlanılmaktadır ${ }^{16}$. Genişleme döneminde özellikle Latin tüccarlar açısından Akdeniz ekonomisinin devamlılı̆ı için Osmanlı pazarı önemli bir konumundaydı. Osmanlı ülkesinde üretilip ticarete konu olan başlıca mallar arasında Avrupa giyim sanayinde kumaş boyalarını sabitleyici olarak 
kullanılan şap, iş gücü desteğini sağlayan köleler ve Cenova ve Venedik gibi büyük şehirlerin gıda ihtiyacı için gerekli olan tahıl gibi kalemler yer almıştır (Fleet, 1999: 81). Osmanlı İmparatorluğu'nda görülen ilk ortaklık niteliğindeki organizasyonlar Avrupa'da olduğu gibi bu mallara olan ihtiyacın dış ticaret yoluyla karşılanmasına dönük olarak kurulmuştur. Bunlar arasında yer alan ilk ortaklık Domenica Doria isimli bir Latin tüccar tarafından şap ticaretine dönük olarak XV. yüzyılın başlarında kurulmuştur. Yüzyılında ortalarında 1449 'da Cenovalı tüccarlar 500.000 kantar şapı kontrol etmek için altı yıllığına oldukça büyük bir başka ortaklık kurmuşlardır. Ortaklık ile hiçbir ortağın bireysel olarak hareket etmesine izin verilmeden sadece ortaklık adına alım ve satım yapmak suretiyle şapın üretim ve satışında tam kontrol sağlanma amacı güdülmüştür ${ }^{17}$ (Fleet, 1999: 81-4). Belirtilen ortaklıkların tamamının dış ticaret amacıyla Latin tüccarlar arasında kurulmuş olması, şirketleşme açısından istisnai bir durum olarak kabul edilebilir. Kayıtlarda Batı'dakinin aksine XIX. yüzyıla kadar Osmanlı tebaası arasında kurulan ortaklıkların sınırlı düzeyde kalmış olması bu durumun açıklanmasında Osmanlı şehirlerindeki üretim ilişkilerinin incelenmesini gerekli kılmaktadır.

Osmanlı şehirlerinde mal ve hizmet üretiminden sorumlu olan loncalar, kendilerine özgü idari, hukuki ve kurumsal yapıları itibarıyla Batı Avrupalı emsallerinden ayrılmakta idiler. Başlangıçta dünyevi anlayış açısından fütüvvet ahlâkını temel alarak faaliyet gösteren loncalar bu yönleriyle bireysel girişim ve kazanç güdüsünü geri planda tutarak organize olmuşlardır. Öte yandan XVII. yüzyıldaki dönüşüm sürecine girene dek Ioncaların sıkı bir devlet denetimine tabi olmaları ${ }^{18}$, Osmanlı loncalarının Batı Avrupa Ioncalarından farklı biçimde özerk bir yapılanmaya sahip olmalarını engellemiştir. Nitekim Batı Avrupa'daki loncalar daha XIV. yüzyılda toplumsal denetim sistemi gibi mekanizmalara geçiş yapıp kendi kendilerini yönetme hakkına sahip özerk üretici/esnaf birimleri olarak tanınmalarına rağmen Osmanlı loncaları hukuki bakımdan tüzel kişilik sahibi birimler olamamışlardır ${ }^{19}$. Bu yetersizlikte İslam hukukunun piyasa merkezli iktisadi ilişkilerde ortak oluşumların yerine bireysel aktörleri onaylayan özelliğinin rolü önemlidir ${ }^{20}$. Piyasa merkezli iktisadi ilişkilerde tüzel kişiliği geri planda tutan bireysellik, devletin de onayıyla loncaların tekelci üretim ve satıcı birimler olarak ${ }^{21}$ kendilerini keşfetmelerini sağlayarak ortaklık oluşumlarının kurulmasını ve büyümesini engellemiş ve modern firmalara dönüşebilecekleri yolları kapamıştır'22 (Kuran, 1999: 108).

Osmanlı İmparatorluğu'nda sermaye ortaklıklarının önünü tıkayan koşullar, XVIII. yüzyıldan itibaren Ioncaların gedik teşkilatlarına dönüşerek çözülmeye başlamaları (Akbaş vd., 2018: 191-2) ve özellikle XIX. yüzyıldan itibaren yabancı malların Osmanlı pazarını ele geçirmesi ile değişmeye başlamıştır. Nitekim hukuki bakımdan şirketleşme bu yüzyılda başlayan sanayileşme çabaları ile resmi olarak gündeme gelmiş ${ }^{23} v e$ 1864 'de kurulan Islah-ı Sanayi Komisyonu'nun girişimleri ile şirketleşme teşvik edilmeye başlanmıştır ${ }^{24}$. Bu amaca yönelik olarak 1866 yılında esnaf şirketleri kurulmuştur. Bununla birlikte simkeşleri, debbağları, saraçları, kumaş̧̧ıları, dökümcüleri ve demircileri bir araya getiren bu şirketlerin bazıları yukarıda belirtilen Ioncaların geciken çözülme süreciyle ilişkilendirilebilecek bilgi ve deneyim eksikliğine bağlı olarak başarılı olamamışlardır (Koraltürk, 1999: 443-4).

Osmanlı İmparatorluğu'nda kurulan ilk anonim şirketin, İstanbul'da toplu taşımacılığa dönük olarak 1850'de kurulan Şirket-i Hayriye olduğu görülmektedir. Anonim şirketler Müslüman girişimciler arasında çeşitli öznel ve nesnel koşullar sebebiyle kısıtlı kalmış ${ }^{25}$ ve II. Meşrutiyet'in ilan edildiği 1908 yılını takiben kurulmaya başlanan "milli şirketler"e kadar anonim şirketler Levantenlerin ve yabancıların tekelinde ilerleme kaydetmiştir. Nitekim 1849-1918 yılları arasında kurulmuş olan toplam şirket sayısı sadece 331 olup bunların önemli bir kısmı Avrupa finans sermayesinin Osmanlı ekonomisine nüfuz etmesi ve hızlı kâr transferi amacıyla kurulmuştur $^{26}$. Ayrıca II. Meşrutiyet'e kadar kurulan şirketler arasında doğrudan sanayi üretimiyle uğraşan şirket bulunmaması, yukarıda belirtilen Osmanlı yerli sanayinin kurulması amacına katkılarının sınırlı düzeyde kaldığını göstermektedir. Öte yandan Batı Avrupa'daki deneyimlere benzer biçimde anonim şirketler yoluyla hissedarlardan toplanan tasarrufların yatırımlara dönüştürülmesi amacı da arzu edilen düzeyin çok gerisinde kalmıştır. Zira ekonomik yönden ne şirketlerin çatısı altında toplanarak yatırıma dönüşebilecek düzeyde bir tasarruf birikimi ne de toplumun bu tür bir tasarruf değerlendirme alışkanlığı mevcut olmuştur (Koraltürk, 1999: 445 $)^{27}$.

Tüm bu sıralanan gelişmelerden Osmanlıda şirketleşme pratiğinin Batı Avrupa deneyimiyle kıyaslandığında oldukça yetersiz düzeyde kaldığı, XIX. yüzyıldaki bazı idari ve yasal düzenlemelere karşın bu 
yetersizliğin giderilemediği sonucuna ulaşılmaktadır. ${ }^{28}$ Ortaklık ve korporasyona dönük kurumsal yetersizlikte, başta yukarıda belirtildiği gibi İslam hukukunun tüzel kişiliği geri planda tutan özelliğinin yanı sıra standartlaştırılmış bir muhasebe sisteminin yokluğu ile özel mülkiyet haklarının zayıflığına bağlı olarak başarılı tüccarların servetlerini ortaklık kurmak yerine vakfedilmek üzere taşınmaza çevirme eğiliminde olmaları temel faktörler olarak değerlendirilebilir (Kuran, 2018: 164).

\section{XIX. YüzyıI Bursa İpekli Sektöründe Kapitalist Dönüşüm ve Sermaye Faktörüne Kurumsal Yaklaşım}

Bursa'da uzak mesafe ticareti için ipekli imalatının tarihi Bizans İmparatorluğu dönemine dayanmaktadır. Bununla birlikte şehrin Osmanlı idaresine geçtiği 1326 yılından itibaren Bursa ipekli dokumaları kalitesi, renkleri ve tasarımıyla ünlenmiştir. Ilerleyen süreçte şehir, ipekli ürünler ticaretinde Osmanlı ülkesinin temel merkezi haline gelmiştir. Bu başarıda şüphesiz Bursa ve çevresinin ipekböceği beslenebilmesi için gerekli dut ağacı yetiştirilmesine uygun iklim şartlarına ve coğrafi yapıya sahip olmasının yanı sıra başta İstanbul olmak üzere iç piyasanın ve Avrupalı tüccarların taleplerini karşılamak üzere zaman içinde sayıları artan tasarımcı ve dokuyucu zanaatkârların ustalıkları önemli rol oynamıştır. Bir başka deyişle Osmanlı idaresindeki Bursa'da ipekli sektörünün gelişme göstermesindeki iktisadi faktör, ipekli ürünlerinin iç ve dış pazarlarda lüks bir dokuma ürünü olarak diğer dokuma ürünlerine göre daha fazla rağbet görmesi, dolayısıyla talep yönünden avantajlı bir ürün olmasıdır. Talep yönünden değinilen farkındalık 1587-1628 arasında Osmanlı İmparatorluğu ve İran arasında süregelen savaşlar sebebiyle İran'dan gelen ham ipek miktarındaki düşüşlere bağı olarak yeni bir boyut kazanmış ve dut ağacı yetiştirmeye bağıı ipek kozası üretimi Bursa'da tarımsal açıdan öncelikli uğraşı haline gelmiştir (Dalsar, 1960: 302-6). Dolayısıyla Osmanlı saray mensupları dâhil çevre vilayetlerde yaşayan askeri ve sivil bürokrasinin yüksek talebinin Bursa'da yerli ve yabancı tüccarları yüksek kâr oranına sahip ipekli ürünlerini pazarlamaya yöneltmesi olgusunun tarımda dut ağacı yetiş̧irilmesi ile imalatta ipekli dokumacılığında üretim sürekliliğinin ve yüksek ürün kalitesinin sağlanmasına yol açtı̆̆ı söylenebilir. Henüz XVI. yüzyılın başında Bursa'da 1000 civarında dokuma tezgâhının bulunmakta oluşu, ipekli dokumadaki uzmanlaşma düzeyi ve pazarın büyüklüğü hakkında fikir verici niteliktedir (Erder, 1976: 89-90). Bursa ve civarında ipekli sektöründeki gelişme eğilimi XVII. ve XVII. yüzyıllarda da sürmüştür. Öyleki XVIII. yüzyılın sonuna gelindiğinde Bursa'da üretilmekte olan ham ipek İstanbul, Halep ve Bursa dokumacılarının talebini karşılayabildiği gibi 300 kantar ham ipek ihracatı gerçekleştirilebilmekteydi. Yine aynı dönem itibarıyla Bursa'da 2000 adet ipekli dokuma tezgâhı çalışır durumdaydı (Küçükkalay, 2001: 253). Quataert (2011: 198) XIX. yüzyılın başında da ipekli dokumacılı̆ı̆ında el emeğine dayalı uzmanlaşmanın devam ettiğini ve tepme mancınık teknolojisinin devreye girmesiyle 18111833 arasında ipekli ürünler imalatının \%25 düzeyinde arttı̆̆ını belirtmektedir.

Uzmanlaşma ve el becerisine dayalı olarak el tezgâhlarında gerçekleştirilen ipekli dokuma ürünlerine olan talep düzeyi 1820'lerden itibaren gerilemeye başlamış ve 1838 Balta Limanı Anlaşması'nın ithalatı düzenleyici hükümlerinin uygulamaya girmesi ${ }^{29}$ sektör düzeyinde bir dönüşümü beraberinde getirmiştir. Dönüşümün gerisindeki temel faktör, İngiliz fabrikasyon pamuklu ürünlerinin Osmanlı pazarına girişi ile başlamış ve Osmanlı ipekli dokuma ürünleri ucuz, kaliteli ve dayanıklı ithal pamuklu ürünlerinin artan rekabeti ile karşı karşıya kalmıştır ${ }^{30}$. Dokumacılıktaki Osmanlı ürünleri aleyhine rekabet eksikliğini doğuran faktör şüphesiz İngiltere'de başlayıp diğer Batı Avrupa ülkelerine yayılan, üretimde buhar makinesinin devreye girmesi olmuştur. Büyük ölçekli ve kaliteli üretimi mümkün kılan bu teknik dönüşümde çalışmanın ilk bölümünde bahsedilen ve yeni üretim tekniğinin üst yapısını oluşturan anonim şirket düzenlemeleri önemli rol oynamıştır. Bu şirketler sayesinde başta Ingiltere olmak üzere Batı Avrupa'daki dokuma sektörü yatırımlarında parasal sermaye sahibi ile yönetici ayırımı gerçekleşmiş ve böylece profesyonel yöneticiler, çoğu zaman yönetim bilgisinden yoksun olan sermaye sahipleri ile aile fertlerinin yerini alarak, risk-kâr dengesini sağlamışlardır. Sonuçta süreklilik gösteren teknik gelişmelerin ortaya çıkardığı maliyet avantajına sahip fabrikasyon ürünler dış pazarlarda büyük bir rekabet üstünlüğüne sahip olmuşlardır (Kazgan, 1999: 33). XIX. yüzyılın ortalarına gelindiğinde ipekli dokuma imalatındaki gerilemenin boyutu üretimin gerçekleştirildiği tezgâh sayısı ile üretilen kumaş miktarındaki düşüşten anlaşılabilir. Buna göre 1860 'ların ilk yarısı itibarıyla Bursa ve civarında ipekli kumaş üretimi 1820'lerdeki düzeyiyle kıyaslandığında \%90 oranında azalmıştır. Aynı dönemde ipek kumaş dokuyan tezgâh sayısında ise \%75 düzeyinde azalma meydana gelmiştir ${ }^{31}$ (Quataert, 
2011: 205). İngiliz pamuklu ürünlerinin piyasada ele geçirdiği rekabet avantajının yanı sıra Bursa'da ipekli dokumacılığın gerilemesindeki diğer faktör, geleneksel yöntemlerle üretilen ipek ipliğinin fiyatının yüksek teknolojili makineyle üretilen ithal iplikten çok daha yüksek oluşudur ${ }^{32}$. Bu verilere dayanarak 1838 Balta Limanı Anlaşması ile serbest ticaret önündeki engellerin ortadan kalkması sonucunda Avrupa menşeli fabrikasyon ürünlerin lehine gelişen artan rekabet koşullarının, Bursa'da ipekli dokuma imalatı bakımından bir erken (prematüre) sanayisizleşme ${ }^{33}$ olgusunu ortaya çıkarmış olduğunu iddia etmek mümkündür.

Osmanlı İmparatorluğu'nun merkez-çevre ilişkisine dâhil oluşunun bir bakıma resmi belgesi niteliği taşıyan 1838 Balta Limanı Anlaşması'yla, Osmanlı ülkesine dokuma ürünleri ihracatını artırmanın yanı sıra Osmanlı ham madde piyasasını liberalleştirmek suretiyle merkeze ucuz ve kaliteli ham madde sevkiyatının sağlanması da amaçlanmıştır. Zira anlaşma öncesinde, dış ticaret mevzuatı gerek ham madde ihracatına kısıtlamalar/yasaklamalar içeriyor, gerekse "yed-i vahit" 34 adı verilen tekelci bir satın alma sistemi ham madde fiyatlarının piyasa koşullarında oluşmasının önünde ciddi bir engel oluşturuyordu. "Yed-i vahit" uygulaması yün, haşhaş, zeytinyağı, tahıllar ve meyankökü gibi tarımsal ham maddelerde olduğu gibi ham ipeği de kapsıyordu. Merkeze ucuz ve kaliteli ham madde sevkiyatını engelleyen söz konusu uygulama 1838 Balta Limanı Anlaşmasının 4. maddesi uyarınca kaldırılmıştır. Buna göre İngiliz tüccarlara Osmanlı Imparatorluğu'nda üretilen bir malı, malın değeri üzerinden \%3 oranında gümrük vergisi ödemeleri koşuluyla hiçbir engelle karşılaşmaksızın ülke dışına çıkarabilmelerine imkân sağlanmıştır. Ayrıca yerli tüccarlar ülke içi mal ticaretinde iç gümrükleri ödemeye devam ederken, yabancı tüccarlar bu uygulamanın dışında bırakılarak önemli bir ayrıcalık elde etmiş oluyorlardı.

Anlaşma ile ham ipek ihracatının önündeki engeller ortadan kalkınca, Bursa ve yöresinde ham ipek imalatı bakımından bir dönüşüm gerçekleşmiştir. Dönüşüm, çoğunluğunu azınlıkların oluşturduğu yerli tüccarlar ile yabancı tüccarların sermaye birikimlerini yukarıda belirtilen merkez-çevre ilişkisine bağı biçimde Fransa'nın Lyon şehri ve çevresinden gelen talebin uyardığı ham ipek imalatı ${ }^{35}$ ve ticaretine yönelik yatırımlarda kullanmaya başlamaları ile işlerlik kazanmıştır ${ }^{36}$. Tüccarların söz konusu yatırımlara girişmelerinde Bursa'da ham ipek imalatında yaklaşık 150 yılı kapsayan bir dönem boyunca değişik üretim organizasyonlarının bir aradaki varlığı önemli rol oynamıştır. Şöyle ki, XVII. yüzyılın sonundan itibaren Bursa ve yöresinde loncaların gerçekleştirmekte oldukları ham ipek imalatı ile Batı Avrupa'daki sanayi kapitalizmine geçişte ön aşamayı oluşturan eve iş verme (putting-out) tarzında üretimin birlikteliği söz konusudur. Buna göre tüccarlar ipek kozasından ipek çekimine dönük sipariş verip imalat için gerekli sermayeyi (ipek kozası, araç-gereç $v b$.) temin ederek evlerde çocuk ve kadınların da dâhil olduğu iş gücünü organize etmişlerdir ${ }^{37}$ (Yıldırım, 1999/2000: 157-8). Tüccarların bu şekilde girişimci rolünü üstlenerek üretim sürecini örgütleyebilmeleri, ham ipek imalatını çalışmanın ikinci bölümünde değinilen Osmanlı İmparatorluğu'ndaki klasik dönem lonca örgütlenmesinin beraberinde getirdiği ham madde ve sermaye temini ${ }^{38}$ kısıtlarından kurtararak aşağıda anlatılacak olan mekanizasyona dayalı üretime geçişin zeminini hazırlamıştır.

Fransa'daki ipekli dokuma sektörünün talep ettiği yüksek dayanıklılık ve kalitedeki ipeğin elde edilebilmesi mevcut ipek çekme teknolojisinde meydana getirilecek icat ve yeniliklere bağlı kalmıştır. Bu durum Bursa'da ipek ipliği teknolojisinde bir dönüşümü gerekli kılmış ve tüccar girişimcilerin başta makine ithalatı olmak üzere yoğun uğraşları sonucunda ipek ipliği imalatında makineli üretime geçilmiştir. İpek ipliği üretiminde kozadan ipek teli çekimi aşamasında kullanılan ve "tepme mancınık" adı verilen ve ayakla çalıştırılan basit bir mekanik aletin yerini alan "buharlı mancınık" söz konusu teknolojik dönüşümün bir simgesi olarak kabul edilebilir ${ }^{39}$. Buharlı mancınık ilk defa 1824 yılında Lyon'da ipekböceği kozasının içinden düzgün ve firesi az biçimde ipek teli çekimini sağlamak üzere geliştirilmiş ve başta Fransa olmak üzere ipekli ürünler imalatı yapılan ülkelerde ${ }^{40}$ kullanılmaya başlanmıştır. Teknolojik gelişmeyle birlikte filatür tesislerinde buhar gücüyle çalışan makinelerin kullanılması, standartlara uygun iplik üretimi için gerekli ipeğin temin edilmesini sağlamakla kalmamış, ipek üreticilerine önemli bir maliyet avantajı da kazandırmıştır. Söz konusu süreç Bursa'da filatür tesislerinin yerli azınlık tüccarlar ${ }^{41}$ tarafından peşi sıra kurulması ile hız kazanmış ve Bursa genelinde buharlı mancınık teknolojisi kullanılan böylesi tesislerin sayısı 1860'lara gelindiğinde 90'a ulaşmıştır (Yılmaz, 2019: 67-9). Ham ipek üretiminde yaşanan söz konusu dönüşüm süreci Tablo 1'den izlenebilir. 
Tablo 1. Bursa Yöresinde Ham İpek Üretim Miktarları (Ton) ve Endüstriyel Üretimin Toplam Üretime Oranı (\%) (1850-1871)

\begin{tabular}{|c|c|c|}
\hline Yıllar & Ham Ipek (Ton) & Endüstriyel Üretim/Toplam Üretim (\%) \\
\hline 1850 & 459 & 9 \\
\hline 1851 & 407 & 11 \\
\hline 1852 & 486 & 16 \\
\hline 1853 & 382 & 22 \\
\hline 1854 & 450 & 20 \\
\hline 1855 & 509 & - \\
\hline 1856 & 534 & 28 \\
\hline 1857 & 366 & 50 \\
\hline 1858 & 242 & 75 \\
\hline 1859 & 178 & 80 \\
\hline 1860 & 193 & 78 \\
\hline 1861 & 299 & 79 \\
\hline 1862 & 195 & 85 \\
\hline 1863 & 280 & 65 \\
\hline 1864 & 197 & 75 \\
\hline 1865 & 127 & 100 \\
\hline 1866 & 153 & 92 \\
\hline 1867 & 165 & 92 \\
\hline 1868 & 131 & 93 \\
\hline 1869 & 141 & 95 \\
\hline 1870 & 141 & 95 \\
\hline 1871 & 153 & 92 \\
\hline
\end{tabular}

Kaynak: Quataert, 2011: 120.

Tablodan izlenebileceği gibi Bursa ve civarında ham ipek üretimine dönük makineli üretime geçişle birlikte 1850 yılında \%9 düzeyinde olan fabrikasyon tarzı üretim miktarı 1865 yılı itibarıyla üretimin tamamını kapsar hale gelmiştir. Toplam ham ipek üretim düzeyindeki değişmeler ise tablonun ilk sütunundan tespit edilebilir. Ham ipek düzeyinde 1850-1856 arasında süreklilik göstererek \%14'ler düzeyine erişen artış eğilimi 1856 'dan itibaren bir düşme eğilimine girmiştir. Söz konusu düşme eğilimi, 1854 yılında Güney Fransa'da ortaya çıkan ve tüm Avrupa'da ipek böceği yumurtalarına zarar veren pébrine isimli bir bakterinin üretim düzeyi üzerindeki olumsuz etkilerine bağlı olarak ortaya çıkmıştı ${ }^{42}$ (Quataert, 2011: 223).

O günkü genel iktisadi koşullar düşünüldüğünde makineli üretime geçişin önemli düzeyde bir sermaye birikimine ihtiyaç göstermesi ve buharlı makinelere dayalı üretim organizasyonunun ücretli iş gücü kullanılarak yürütülmesi, ${ }^{43}$ ham ipek üretiminde kapitalist ilişkilerin geçerliliği yönünde bir dönüşümü gerekli kılmıştır. Bu tespitten hareketle Bursa ve yöresinde ham ipek sektöründeki kapitalist dönüşümde tüccar sermayesinin üretim ve pazarlama sürecindeki işlevinin incelenmesi, ipekli sektöründeki kapitalist dönüşüm sürecinin genel olmaktan ziyade özel niteliğini ortaya koyabilecektir.

Ham ipek imalatı bakımından değerlendirildiğinde ipek kozalarını bozulmadan birkaç hafta gibi kısa bir süre ${ }^{44}$ zarfında satın almak için hazır ve fazla miktarda bir nakdi sermayeye ihtiyaç göstermesi, filatür tesisi 
yatırımı için öncelikli bir sermaye kısıtı oluşturmuştur. Çalışmanın ikinci bölümünde değinildiği gibi banka benzeri kredi verebilecek kurumların olmadığı koşullarda söz konusu sermaye kısıtının aşılması oldukça güç görünmektedir. Öte yandan yine çalışmada daha önce vurgulandığı gibi İslam hukukunun Avrupa'dakinin tersine tüzel kişiliğe sahip kurumsal organizasyonların kurulmasını güçleştiren özelliğine bağlı olarak bölgede başta dokumacılar olmak üzere yerli zanaatkârlar ile Müslüman tüccarların koza alımındaki sermaye engelini aşabilseler dahi filatür tesisi kurabilme noktasında bir ortaklık kurmalarının oldukça zor olduğu sonucuna varılabilir ${ }^{45}$. Nitekim o yıllarda Bursa'da ikamet eden ve ipek ticaretiyle uğraşan Sardunya Viskonsülü Terraneo'nun derlediği veriler, 1855 yılı itibarıyla kurulu bulunan 22 tesisten sadece üçünün sahiplerinin yabancılar ve azınlıklar haricindeki yerli girişimciler olduğunu göstermektedir (Kağıtçıbaşı ve Yaşar, t.y.). Bölgedeki yerli azınılı ve yabancılardan oluşan tüccarların yatırım için gerekli sermaye teminini kolaylaştıran önemli faktör ise bu kişilerin Avrupa bankaları ve finans kurumlarından uygun koşullarda kredi temin edebilmeleri olmuştur. Nitekim XX. yüzyılın başı itibarıyla bölgedeki filatür tesisi sahiplerinin etnik yapısına bakıldığında, bunların çoğunluğunu başta Ermeni ve Rum yerli azınlıklar ile yabancıların oluşturduğu görülmektedir (Ökçün, 1984: 140-1).

Bursa ve yöresindeki filatür tesisi yatırımlarındaki sermaye sahipleri daha detaylı incelendiğinde karşımıza sermayenin sarraf-yabancı/azınlık tüccar-bürokrat arasında kurulan ortaklıklar yoluyla büyütülerek yatırıma dönüşebildiği bir süreç ortaya çıkmaktadır. Her ne kadar Lyon bölgesinin yüksek düzeyli ham ipek talebi yatırımların temel uyaranı olsa da Osmanlı maliyesinin içine düştüğü gelir-gider açmazına ${ }^{46}$ bağlı olarak ortaya çıkan sarraf-tüccar-bürokrat arasındaki karşılıklı çıkar ilişkileri, sermaye ortaklıklarının önünü açan önemli bir faktör olarak değerlendirilebilir. Söz konusu çıkar ilişkilerinin teşekkülünde 1839 Tanzimat Fermanı'nın hukuki ve siyasi açıdan özel mülkiyet konusundaki meşrulaştırıcı etkisi ile Osmanlı vatandaşları arasında piyasadaki rol ve işlevlerin belirlenmesindeki etnik ve dini temelli ayrımı ortadan kaldıran eşitlikçi niteliği önemlidir. Osmanlı merkezi idaresi ferman öncesinde eksilen merkezi karar alma ve uygulama gücünü ferman ile artırma gayretinde olmuşsa da özel mülkiyet hakkının Osmanlı tebaasını oluşturan unsurlar arasında eşit düzeyde tanımlanmış olmasının, kapitalist ilişkilere dayalı ortak yatırımların gerçekleştirilmesinde etkili olduğu iddia edilebilir (Keyder, 1999: 277).

Bu bağlamda belirtilmesi gereken önemli bir husus da 1838 Balta Limanı Anlaşması uyarınca ipek kozalarının Osmanlı ülkesi dışına satışına engel olma imkânının ortadan kalkmış olmasıdır. Bu duruma bağlı olarak anlaşmayı izleyen süreçte Osmanlı İmparatorluğu'nun ipek ihracatından elde ettiği vergi gelirleri düşmeye başlamıştır. Nitekim anlaşmayı izleyen bir sene içinde 50.000 kıyye (okka) koza yurt dışına ucuz fiyatla satılmıştır (Manav, 2019: 78). Değişen koşullar devleti filatür tesislerinin ülke içinde kurulmasını desteklemeye dönük bir yaklaşım içinde olmaya itmiştir. Bununla birlikte kurulum maliyetinin yüksekliği, filatür tesislerini devletin kendi kaynaklarıyla kurmasını güçleştirmiştir. Bu koşullarda devlet tarafından bir çözüm yolu olarak iltizam sistemi uyarınca bölge düzeyinde ipek aşarını alacak servet sahibi kimselerin bu yetki karşılığında tesis kurma taahhüdünde bulunması uygulaması benimsenmiştir. Uygulama tüccarlarla yakın finansal ve ortaklık ilişkileri bulunan sarraflar aracılığıyla gelişme göstermiştir. Bu dönemde neredeyse tamamının gayrimüslim tebaadan olmaları, sarrafların özellikle yabancı tüccarlarla geniş bir iletişim ağı oluşturmalarına yol açıyor ve sarraflar kurulan ticaret acenteleri üzerinden merkez-çevre ilişkisi kapsamında Avrupa'ya gönderilen hububat, ipek, tütün $v b$. tarımsal ham maddelerin ihracat işlemlerinde özellikle liman şehirlerinde finansör rolü üstleniyorlardı. Ayrıca özellikle yerli Rum banker ve sarraflar tüccar ortakları ile faiz haddi nispi olarak düşük kredilerle, Batı'dan getirdikleri ve satın aldıkları malları, ülke sınırları içinde peşin para ile satarak ellerinde biriken fonları birkaç misli faizle bu malları pazarlayanlara ve tüketicilere kredi olarak kullandırıyorlardı (Kazgan, 2005: 14).

Bu sarraflardan biri olan Mıgırdiç Cezayirliyan, Bursa'da XIX. yüzyılın ilk yarısında faaliyete geçen üç büyük filatür tesisinin kurucusu olup yatırımlarını yukarıda belirtilen sarraf-tüccar-bürokrat çıkar ve ortaklık ilişkisi çerçevesinde gerçekleştirmiştir. Cezayirliyan, yatırımlara girişmeden önce Maliye Nazırı Safveti Paşa'nın telkin ve desteği ${ }^{47}$ ile Bursa yöresindeki ipek iltizamını almak ${ }^{48}$ amacıyla senelik 50.000 lira ödenmesi koşuluyla altı yıllık 300.000 liralık bir teklif vermiştir. İhalenin bir başka koşulu filatür tesisleri kurulması olarak belirlenmiştir. Bu nedenle Cezayirliyan verdiği teklifte ilave olarak Avrupa'daki örnekleri gibi buharlı mancınık kullanarak ipek çekme işlemi yapan filatür tesisleri kurmayı da taahhüt etmiştir (Manav, 2019: 75) ${ }^{49}$. 
Cezayirliyan iltizam hakkını elde etmesinin ardından Bursa, Mudanya ve Bilecik'te toplam dört filatür tesisi kurmuş ve finansmanını sağladığı bir diğer mültezim Abdülkadir Paşa ile olan ortaklığı sayesinde Bursa ile Mudanya yöresindeki ipek ticaretindeki gümrük vergilerini toplama ve kontrol etme hakkına da sahip olmuştur. Öte yandan Cezayirliyan'ın borç alacak defterlerinden elde edilen kayıtlar, ortağı olan Fransız tüccar Malton'a ihraç edilmek üzere tesislerde çekilen ipek ipliği sattı̆̆ını ortaya koymaktadır (Manav, 2019: 74). Tüm bu ilişkiler beraberce değerlendirildiğinde, Cezayirliyan'ın mekanizasyona dönük yatırımlara girişmesindeki motivasyon ve sermayenin sarraf-tüccar-bürokrat iş birliğine bağlı olarak ortaya çıkmış olduğu ve kullanıldığı anlaşılmaktadır.

Mekanizasyona dönük sermaye yatırımlarında sarraf-tüccar-bürokrat iş birliği zincirinin bürokratik halkası Sarım Paşa deneyiminden anlaşılabilir ${ }^{50}$. Sadrazamlık ile çeşitli bakanlık (hariciye, maliye ve ticaret) görevlerinde bulunmuş olan İbrahim Sarım Paşa, mekanizasyona dayalı olmaksızın sadece ipek çekim ustalarını bir araya getirip imalat yapmaktan ibaret olan filatür tesisini 1851 yılında kurmuştur. Kullanmakta olduğu teknolojinin yetersizliğini kavrayan Sarım Paşa, Fransız yapımı buharlı makineleri tesisine adapte etmesinin ardından şehrin ölçek bakımından en büyük üreticisi haline gelmiştir. Bir müddet sonra tesis sayısını ikiye çıkaran Sarım Paşa üretiminin tamamını Lyon'daki ipekli kumaş fabrikalarının ihtiyacını karşılamaya dönük olarak Fransa'ya ihraç etmeye başlamış ve Fransa piyasasında bir marka haline gelmiştir (Erder, 1976: 106-7). Sarım Paşa'nın söz konusu başarısı, yatırım için gerekli sermayenin gelişmiş teknolojinin adaptasyonu ile kapitalist tarzda organize edildiği koşulda ham madde düzeyinde de olsa merkez ülke pazarlarında bir marka/patent sahibi olunabileceğinin bir kanıtı olarak değerlendirilebilir.

Bürokrat olması itibarıyla Sarım Paşa ile benzerlik gösteren ancak başarısızlıkla sonuçlanan bir filatür tesisi girişimi Sultan II. Mahmut'un kâtibi olan Mustafa Nuri Paşa'ya aittir. Mustafa Nuri Paşa tesisinde hidrolik sistem kullanarak mekanizasyonu ipek çekimi ve kurutmanın ötesinde bir biçimde genişletmeye çalışmış ancak işletme sermayesi yetersiz tesisini yabancı bir İstanbul firması olan Jacques Clavany et Cie'ye kiralamak zorunda kalmıştır (Erder, 1976: 102-3).

Yukarıda sıralanan gelişmelerden Bursa ve civarında ham ipek imalatına dönük olarak sermayenin organizasyonu bakımından kurumsallaşmanın formel düzeyde Batı Avrupa deneyiminde görüldüğü gibi anonim şirket niteliğinde olmayıp adi ortaklık düzeyinde gerçekleştiği, dolayısıyla sermayenin tabana yayılamadığı anlaşılmaktadır.

Bursa'da özel şahıslar haricinde filatür tesisi kurulup işletilmesine dair bir girişim ise bizzat devlet tarafından gerçekleştirilmiştir. Devlet İzmir'deki Basmane Fabrikası ve İstanbul'daki Feshane Fabrikası'nın bir benzerini Bursa'da "Harir Fabrika-yı Hümâyunu" adıyla 1845 yılında işletmeye açmıştır. Bölgedeki birçok tesiste olduğu gibi üretimde Fransız yapımı makinelerin kullanıldığı bu tesisin kuruluş amacı özel şahıslarınkinden farklı biçimde dış talebin karşılanmasına dönük olmayıp tamamen İstanbul'daki saray çevresinin ipekli dokuma ve halı ihtiyacını karşılamaya dönük Hereke'deki dokuma tesisinde ham madde olarak kullanılan ipek ipliğini üretmekti (Yılmaz, 2019: 70) ${ }^{51}$. Tesisin özel girişimlerden farklı olarak onlardan daha önce mekanizasyona geçme ve üretimi artırma olanağı bulunuyordu. Ayrıca yatırım sermayesi için gerekli araçlara sahipti çünkü gerektiğinde sübvansiyona bağlı fiyat ayarlaması yapabiliyordu. Tesis, yaş koza işleme kapasitesinin genişliğiyle ipek sektörüne önemli katkı sağlamakla birlikte devlet işletmeciliğine münhasır bazı yetersizlikler sebebiyle üretim ve verimlilik düzeyi açısından özel girişimlerle kıyaslandığında etkin olamamışı ${ }^{52}$. Aynı durum yeni imalat tekniklerinin devreye girmesi bakımından da geçerli olmuştur Erder $(1976)^{53}$.

Bursa ve yöresinde işletmeye açılan filatür tesislerinin önemli bir kısmının XX. yüzyılın başına dek üretimlerini sürdürmüş olmaları, bir çevre ülkesinde dış talep ile uyarılan fabrikasyona yönelik girişimlerin ham madde üretimi düzeyinde de olsa kârlılık açısından başarılı olduğunu ortaya koymaktadır. Bununla birlikte sarraf-tüccar-bürokrat ortaklığının organize ettiği sermayenin kullanılması suretiyle elde edilen iktisadi başarı bu tesisler ile sınırlı kalmış ve ilave yatırımlara ya da başka sanayi yatırımlarına dönüşememiştii ${ }^{54}$. Sermaye sahipleri elde etmiş oldukları kazançları alternatif girişimlerde kullanmak yerine servetlerini büyütmek, borç vermek, kira geliri elde etmek gibi üretken olmayan faaliyetlerde kullanmayı yeğlemişlerdir ${ }^{55}$. Bu durumun oluşmasında sarraf-bürokrat-azınlık tüccar arasında kurulan ortaklıkların 
yukarıda ifade edildiği gibi kurumsallaşma açısında Batı Avrupa şirketleşme deneyiminden farklı niteliği temel etken olarak kabul edilebilir. Söz konusu temel etkenin yanı sıra İmparatorluğun iktisadi olduğu kadar siyasi konjonktüründeki değişmelerin etkisij ${ }^{56}$ ve Osmanlı dış borçlarının geri ödenebilmesi amacıyla 1881'de kurulan Düyun-u Umumiye İdaresi'nin ham ipekte alıcı tekeli haline gelmesi, sermaye sahiplerinin söz konusu tercihlerinin ardındaki diğer etkenler olarak değerlendirilebilir.

\section{Sonuç}

Çalışmada Osmanlı İmparatorluğu'nda XIX. yüzyıldaki sanayileşme çabalarında ortaklık/şirketleşme yetersizliğine bağlı sermaye sorunsalı Bursa ipekli sektörü örneği üzerinden değerlendirilmiştir. Bu kapsamda 1838 Balta Limanı Anlaşması hükümlerinin uygulamaya girmesinin ardından Bursa ve yöresinde yüzyıllardır geleneksel yöntemlerle gerçekleştirilen ipek ipliği imalatında, sektörün nihai ürünü olan ipekli dokumada meydana gelen sanayisizleşmenin aksine gerçekleşen kapitalist dönüşüm süreci ortaya koyulmuştur. Merkezçevre ilişkisi çerçevesinde Fransa ağırlıklı olmak üzere merkezin dokuma sektöründeki artan iplik talebinin uyarması sonucunda gerçekleşen kurumsal dönüşüm, ücretli iş gücü kullanılarak buharlı makinelerle üretimin yapıldığı filatür tesislerinin kurulmasıyla gerçekleşmiştir. Çalışmada filatür tesislerinin kuruluşu için gerekli sermayenin azınlıklar ve yabancı tüccarların sarraf ve bürokratlarla kurmuş oldukları resmi ve zımni ortaklıklar yoluyla sağlanmış olduğu anlaşılmıştır. Tüccarların girişimci olarak dönüşüm sürecindeki etkin rolü, Bursa'da XVII. yüzyılın sonundan itibaren ham ipek imalatında geleneksel Osmanlı lonca imalatı haricindeki fason imalata dönük farklı üretim ilişkilerinin varlığıyla ilişkilendirilmiştir. Çalışmada elde edilen bir diğer sonuç ise sermayenin çevrede ortaklık formunda kurumsal olarak organize edilebildiği koşulda gerçekleşen kapitalist tarzda uzmanlaşmanın, nihai üründe olmasa da Bursa ipek sektörü örneğinde ham madde-ara malı üretimi düzeyinde sanayileşmeyi sağlayabildiği yönünde olmuştur. Sanayileşme açısından ham madde ve ara malında elde edilen başarı ise nihai ürüne ve diğer tekstil imalatına nüfuz etmemiştir. Bu yetersizlikte kurumsallaşmanın Batı Avrupa şirketleşme deneyiminden farkı niteliğinin yanı sıra Düyun-u Umumiye İdaresinin kurulmasıyla gerçekleşen mali ve sosyoekonomik konjonktür değişikliği temel faktörler olarak değerlendirilmiştir.

\section{Beyan ve Açıklamalar (Disclosure Statements)}

1. Bu çalışmanın yazarları, araştırma ve yayın etiği ilkelerine uyduklarını kabul etmektedirler (The authors of this article confirm that their work complies with the principles of research and publication ethics).

2. Yazarlar tarafından herhangi bir çıkar çatışması beyan edilmemiştir (No potential conflict of interest was reported by the authors).

3. Bu çalışma, intihal tarama programı kullanılarak intihal taramasından geçirilmiştir (This article was screened for potential plagiarism using a plagiarism screening program).

\section{Son Notlar}

1. Kurumsal iktisat okulu, iktisat teorisinin odağına kurumları yerleştirerek iktisadi olayların analizinde neoklasik iktisadi yaklaşımın marjinalist ilkelere dayalı piyasa analizinin yetersizliğini giderme çabasında olan bir iktisat okuludur. Kurumsal iktisat okulu mensupları analiz yöntemi olarak iktisadi düşüncenin zorunlu bir biçimde kurumlar tarafından belirlendiği, sınırlandığı, biçimlendiği ve yönetildiğini savunmaktadır. Okulun kendi içerisinde birbirine benzeyen, ancak neoklasik iktisadın varsayımlarına olan yakınlık/uzaklık bakımından ayrışan iki temel yaklaşımı bulunmaktadır. Bunlar Asıl (Eski) Kurumsal iktisat ve Yeni Kurumsal iktisattır. Asıl Kurumsal iktisat indirgemecilikten çekinmekte ve rasyonel birey varsayımına bütünüyle karşı çıkmaktadır. Yeni Kurumsal iktisat ise neoklasik iktisadı ikame edici değil, bütünleyici bir yaklaşım sergilemekte ve disiplinler arası çalışmalar ile ampirik araştırmalara ağırlık vermektedir. iki yaklaşım arasındaki temel benzerlik ise ana akım iktisadın tam bilgi, sınırsız rasyonellik ve işlem maliyetlerinin yokluğu varsayımlarını kabul etmemeleridir (Seçilmiş, 2016: 13).

2. “Commenda"'nın kökenleri konusundaki tartışmalar devam etmekle birlikte hâkim görüş, "commenda"'nın kökenlerinin büyük olasılıkla islam dünyasındaki uygulamalara dayandığını savunmaktadır. Buna göre Modernlik öncesi Ortadoğu'da Müslümanlar, aktif tüccarlar ile pasif yatırımcılar arasındaki ilişkilerin islam hukuku tarafından 
düzenlendiği, Avrupalılardan çok daha gelişmiş ticaret yöntemlerine sahip idiler. Yöntemlerden biri, tüm girişim sermayesinin yönetimde yer almayacak bir ya da daha fazla yerleşik yatırımcı tarafından sağlandığı "mudarebe" idi. Bir diğer seçenek ise, tüccarların da finansmana katkıda bulunmasına dayanan "müşareke" ya da "inan" olarak anılıyordu. Ortaçağ İtalya'sının kıyı kentlerinde kullanılan ortaklık biçimlerinin de girişimi yürüten ve sınırsız sorumluluk taşıyan aktif ortaklar ile sermayeye katkıda bulunan ve yönetime katılmaksızın ya da yatırımının ötesinde risk taşımaksızın kârı paylaşan pasif ortaklar arasında gerçekleşiyor olması, "commenda"'nın kökeninin islam dünyasındaki uygulamalara dayandığı savını güçlendirmektedir (Kuran, 2018: 73-74).

3. Kapitalizm haricindeki toplumsal sistemlerde sınıfsal farklılaşma temelinde oluşmuş ideolojik kurumsal yapılar söz konusu olmadığından din, gelenek, etnisite, askeri güç vb. toplumsal faktörler kurumların fonksiyonları üzerinde belirleyicidir (Godelier, 1978: 765). Karşılıklı güven esasına dayanan ticari işleyişi bu kapsamda değerlendirmek uygun görünmektedir.

4. Ingiltere'de ilk tekel haklarına sahip anonim şirket 1555'te kurulan Muscovy Company olmuş, 1600'de kurulan The English East India Company (Ingiliz Doğu Hindistan Şirketi) ile 1602'de kurulan Vereenidge Oost-Indische Compagnie (Hollanda Doğu Hindistan Şirketi) Hindistan'da ve Avrupa'da milyonlarca insanın hayatını değiştirmiştir. Kraliçe I. Elizabeth'in verdiği imtiyaznamenin ardından dünya ölçeğine yayılan Ingiliz Doğu Hindistan Şirketi’nin faaliyetleri XIX. yüzyılın sonuna gelindiğinde dünya coğrafyasının beşte birini, nüfusunun ise dörtte birini kapsar hale gelmiştir (Yülek, 2019: 58-59).

5. Batı Avrupa miras hukukunun ortaklık ve korporasyonları kolaylaştırıcı niteliği ve siyasi otoritenin teşvik edici uygulamaları için bk. Kuran (2018).

6. Nakdi/para sermayenin kapitalist sistemin işleyişindeki rolünü açıklayabilmek için sermaye sahibi olarak kapitalisti sermayenin değerlendirilmesi bakımından üç kategori halinde ele almak uygun görünmektedir. Bu kategoriler; tüccar kapitalist, sanayi kapitalisti ve para kapitalisti olarak ifade edilebilir. Bunlardan para kapitalisti sermayenin devir sürecinde "borç veren" konumundadır. Borç veren, parasını sermaye olarak kullandırmaktadır, onun bir başkasına verdiği değer miktarı sermayedir ve bu nedenle kendisine geri dönmektedir. Ne var ki sırf bu dönüş, borç verilen değer miktarının sermaye olarak geriye akışı anlamına gelmeyebilir, sadece borç verilen değerde miktarın geri dönüşü olabilir. Sermaye olarak geri dönmesi için yatırılan değer miktarının, hareket sırasında yalnız kendisini koruması değil, aynı zamanda genişlemesi, değer olarak artması yani bir artı-değerle birlikte " $P+\Delta P$ " olarak geri dönmesi gerekir ki buradaki $\Delta P$, faiz ya da ortalama kârın bir kısmı olup, aktif kapitalistin (tüccar ya da sanayicinin) elinde kalmayarak para kapitalistin payına düşer. Faiz karşılığında geri ödenmesi gereken miktarın haricindeki kısmın yani artı değerin oluşabilmesi ise ticari kapitalizmden farklı olarak sanayi kapitalizminde borç alınan para sermayenin sanayici kapitalist tarafından başta emek olmak üzere üretim araçlarının satın alımında kullanılması gerekir. Üretim araçlarının satın alınmasıyla "üretken sermayeye" dönüşen para sermaye, üretim süreci içerisinde emek faktörünün kendi değerinin üzerindeki bir değeri üretmekte olduğu metaya aktarma olanağını sağladığı için süreçten büyümüş olarak çıkar. Sürecin nihai kısmında sanayici kapitalist artı değeri içeren meta formundaki sermayeyi pazarda tekrar paraya dönüştürerek borç olarak almış olduğu sermayenin devir sürecini tamamlamış olur (Marx, 1997: 300-1).

7. Söz konusu sektörlerden biri XVII. ve XVIII. yüzyıllarda büyüyen uluslararası deniz taşımacılığıdır. Avrupa'dan Asya'ya XVI. yüzyılda 770 Avrupa gemisi yelken açarken, bu sayı XVIII. yüzyılda 6.661'e ulaşmıştır (Kuran, 2018: 155).

8. Anonim şirketler geç XVII. yüzyıldan itibaren Londra Borsası'nda işlem görmeye başlamış ve yüzyılın sonuna gelindiğinde Ingiltere'de 4 milyon pounddan fazla sermayesi olan anonim şirket sayısı 140'a ulaşmış ve şirketlerin hisseleri için gelişmiş bir finans piyasası oluşmuştur (Smith, 1929: 206).

9. Ülkeler arasında uluslararası düzeyde eşitsiz meta mübadelesi aracılığılla meydana gelen sosyoekonomik ve kültürel sömürü mekanizması iktisat yazınında ilk defa Bağımlılık Okulu tarafından "merkez-çevre" ayrımı ile kavramsallaştırılmış ve I. Wallerstein tarafından kurgulanan "modern dünya sistemi" ile modelleştirilmiştir. Modelde Wallerstein kaynağını teknolojik üstünlüğün oluşturduğu, iktisadi yönden üretim ve pazarlama gücüne sahip ülkeleri "merkez ülkeler" olarak tanımlamakta, "periferi (çevre) ülkeler" yerine "çevre alan-bölgeler" ifadesinin kullanımını tercih etmektedir. Söz konusu tercihin sebebini ise çevre bölgelerde yerel devletlerin de facto zayıf olmasına dayandırmaktadır. Zayıfığın derecesi ise hiç var olmamaktan (tam sömürge durumundan) düşük bir özerklik derecesine (yarı/yeni sömürge olma) durumuna kadar uzanan bir yelpazede değerlendirilmektedir (Wallerstein, 2004: 361).

10. Osmanlı geleneksel iktisadi düşünce sistemi iaşe (provizyonizm), gelenekçilik ve fiskalizm olmak üzere üç ilkeye dayanmakta idi. Bunlardan iaşe ilkesi iktisadi faaliyete tüketici merkezli bakıyor ve insanların ihtiyaçlarının karşılanması amacıyla üretilen mal ve hizmetlerin olabildiğince bol, kaliteli ve ucuz tedarikini esas alıyordu. Gelenekçilik ilkesi ise iktisadi ilişkilerde oluşan değişime dönük eğilimlerin mümkün olduğunca engellenmesini ve değişme ortaya çıktığı takdirde eski dengeye dönmek üzere değişmeyi ortadan kaldırma iradesinin hâkim olmasını 
öngörüyordu. Son olarak fiskalizm ilkesi ekonomide yaratılan artıktan devlete aktarılan payın yüksek tutularak devlet gelirlerinin mümkün olan en yüksek düzeye çıkarılmasını hedefliyordu (Genç, 2012).

11. Osmanlıda bireysel rasyonalitenin Weberyan yaklaşımla "özsel rasyonalite"ye benzediği ileri sürülebilir. iktisadın temel karar birimi olan "homo-economicus"un davranışını tanımlayan formel (araçsal) rasyonellik, teknik olarak niceliksel hesaplamaya dayanan türden eylemler için geçerli iken, özsel rasyonellik, benimsenen bir değerler kümesinin uyardığı türden eylemler için geçerlidir. Özsel rasyonellikte bireyin eylemleri, formel rasyonelliğin bakış açısından ne kadar "akıl dışı" görünürse görünsün, bu türden bir toplumsal değerler ve anlamlara uygun olmak zorundadır (Özel, 2015: 38). Söz konusu değerler arasında dini, ahlaki, geleneksel, kültürel vb. ölçütler davranış biçiminin piyasa rasyonalitesi haricinde tezahür etmesinde etkili olmaktadır. Osmanlı iktisadi zihniyetinin Weberyan subjektif (özsel) rasyonalite bağlamında analizi için ayrıca bk. Bozpinar (2020).

12. Osmanlı arşiv kaynaklarında en sık rastlanan borçlanma biçimi murabahadır. Murabaha, Arapça ticari kazanç, kâr anlamına gelen ribh kökünden türeyen ve aslen bir malın maliyetinin üzerine bir miktar kâr eklenerek satılmasına dönük bir tür güvene dayalı satış sözleşmesi anlamında bir fıkıh terimi olsa da Osmanlı Imparatorluğu'nda "faizle borç para vermek" anlamında kullanılmıştır. Kelimenin toplumsal algılanış biçimi de tarihsel koşullardaki dönüşümlere paralel olarak değişmiştir. XVI. yüzyılda nötr ve temiz bir kazancı ifade etmek için kullanılırken, XIX. yüzyıla kadarki süreçte doğrudan üreticilerin gittikçe daha sık ve daha ağır koşullar altında ezilmelerine neden olması itibarıyla kelime de giderek olumsuz koşul ve durumlara işaret eden bir anlam kazanmıştır. Murabaha işleminde krediyi veren taraf arşiv kaynaklarında murabahacı, tefeci, muameleci gibi farklı adlarla anılmakta, faizin ve anlaşmanın koşullarının çok ağır olduğu durumlarda da kendilerinden çoğunlukla muhtekir ve tamahkâr olarak bahsedilmektedir. Krediyi sağlayan kişilerin, yaygın önyargıların aksine gayrimüslim tebaadan ya da Avrupalı tüccarlardan ibaret olmadığı; Müslüman tebaanın da söz konusu kredi işlemlerinin öznelerinden olduğu henüz erken dönem çalışmalarında ortaya koyulmuştur. Krediyi verenlerin etnik ve dini kökeni için geçerli olan heterojen yapı bu kişilerin sınıfsal konumları bakımından da geçerlidir. Bu konuda yapılan çalışmalar genel bir yargı olan, alacaklıların homojen nitelikte küçük bir zengin elit tabakadan oluştuğu tezini doğrulamamaktadır. Nitekim borcu verenler; yerel ileri gelenler, askeri sınıf, ulema, tüccarlar, sıradan köylüler, sarraflar, mültezimler ve yerel devlet görevlileri gibi son derece geniş kesimleri kapsamıştır (Gündoğdu, 2019: 6).

13. Osmanlı mahkeme kayıtlarından pek çok yörede başlangıçta tamamen yardım amaçlı para vakıflarının kurulmuş olduğu anlaşılmaktadır. Örneğin 1676 yılında Bursa vilayetinin Karaca Muhiddin semtinde ikamet eden Ali B. Hasan isimli bir kişi Hasan Çelebi Mehmed isimli bir kişiyi yeddi-emin atayarak 50 Esedi kuruş sermaye ile bir para vakfı kurmuştur. Vakfın kuruluş hükmü gereğince söz konusu sermaye yüzde 10 ila yüzde arasında bir faiz karşılığında teminatı sağlam olan kişilere borç olarak kullandırılacaktı. Borcun geri ödenmesinin ardından elde edilen meblağın ise her yılın (miladi takvim itibarıyla Ekim sonu-Kasım ayına denk gelen) Rebiülevvel ayının 12'sinde Bağlar bölgesindeki zaviyede fakirlere yemek dağıtımı amacıyla kullanılması öngörülmüştü (Çizakça, 2004: 4).

14. Çizakça (2004: 11) yapmış olduğu çalışmasında vakıflarca işletilen paraların geri ödemesinde istenilen faizin istanbul ve Ankara'daki sarrafların uyguladıkları faiz oranının oldukça altında olduğuna işaret etmektedir. Bu durumda Osmanlı Imparatorluğu'nda para vakıfları sayesinde ikili bir kredi piyasasının oluştuğu ve sermaye ihtiyacı olanların gayrimüslim tebaa tarafından uygulanmakta olan faiz oranından çok daha uygun orandan borçlanma olanağına sahip oldukları sonucu çıkmaktadır. Öte yandan çalışmada bazı vakıf yeddi eminlerinin vakıftan aldıkları paraları sarraflara borç vererek arbitraj geliri elde ettikleri sonucuna da ulaşılmıştır.

15. Sarraflar Osmanlı Imparatorluğu'nda XVI. yüzyılın ortalarından itibaren iltizam sisteminin ayrılmaz bir parçası haline gelmişlerdir. Iltizamlarda, mültezimleri destekleyen ve peşin tutarı onlar adına ödeyen, dolayısıyla devletin vergi tahsilâtını güvence altına alan sarraflar bulunmaktaydı. Bu sistemde, mültezimlere ihale edilen iltizamın, hazineye bir kısmı peşin bir kısmı da taksitle ödenmesi gereken bedeli, onlar adına sarraflarca karşılanmaktaydı. Hükümet mali gücü olan sarrafları iltizam sistemi içinde tutmakla hem hazine gelirini güvence altına alıyor hem de bir banka gibi örgütlenmiş bu kişiler sayesinde vergilerin ülkenin her yerinden merkeze ulaşmasını sağlamayı amaçlıyordu (Manav, 2019: 28).

16. Sultan II. Mehmet döneminden başlayarak imparatorluğa dâhil olan farklı etnik ve dini kökene sahip unsurlara hoşgörüyle yaklaşılması ve özellikle Bizans döneminde ticaret yapmakta olan kişilere ticaretlerini kolaylaştırıcı uygulamalara gidilmesi, imparatorluğun yabancı ülkelerle olan ticari ilişkilerinin giderek güçlenmesini sağlamıştır.

17. Kayıtlardan şapın gideceği yerler, fiyatlar, kira, anlaşmalar ve miktarlar üzerine talimatların hepsinin üyeler arasından seçilen dokuz tüccardan oluşan bir grubun kontrolü altındaki ortaklık tarafından belirlendiği anlaşılmaktadır. Bu durum Osmanlı imparatorluğu'nun önemli bir ihracat maddesi olan şap açısından bir Cenova kartelinin önemli seviyede etkili olduğuna işaret etmektedir (Fleet, 1999: 81-4).

18. Osmanlı loncaları bir yandan şehirlerin iaşesi başta olmak üzere halkın temel ihtiyaçlarının karşılanmasını sağlayarak mal kıtlıkları durumunda oluşabilecek toplumsal tepkiler karşısında bir emniyet supabı işlevi görüyor diğer yandan 
devlet açısından önemli bir vergi kaynağı oluşturuyordu. Bu nedenlerle Osmanlı loncaları daima devletin koruyup desteklediği ama bir yandan da denetimi elden bırakmadığı kurumlar olmuşlardır. Osmanlı loncalarının özerklik düzeyleri ise ayrı bir tartışma konusu olmakla birlikte bu düzeyin loncalar arasında farklıık gösterdiği ve XVI. yüzyılın sonundan itibaren bazı loncaların işleyiş koşullarındaki serbesti derecesinin arttığı ileri sürülmektedir. Nitekim istanbul'da her zanaat için tespit edilmiş olan dükkân ve atölye kotasının artmasını takiben ihtisab düzenlemesinin uygulamada etkinliğini yitirmeye başlayarak fiyatların düzenlenmesinde tek yetkili olan muhtesibin artık eskisi gibi yetkin olmadığı ve fiyatları çoğunlukla esnafın kendisinin belirlemeye başladığı gözlenmiştir. Benzer biçimde XVII. yüzyılda loncaların sadece fiyatları değil, dükkân sayılarının artırılıp artırılmayacağı üzerinde de doğrudan müdahale etmeye başlamış olmaları da loncaların özerklikleri konusunda bir dönüşümün ortaya çıkmış olma olasılığını güçlendirmektedir (Yıldırım, 1999/2000: 155). Bununla birlikte Batı Avrupa deneyimiyle kıyaslandığında dönüşüm hem yavaş bir şekilde gerçekleşmiş hem de loncaların tam anlamıyla çözülmeleri, 1853 yılında ticarette kabul edilmiş olan "inhisar usulü"'nün kaldırılmasını takiben XIX. yüzyılın ikinci yarısını bulmuştur (Koyuncu, 2018: 61).

19. Osmanlı loncalarının hukuken özerk olmayışlarının önemli bir göstergesi, aldıkları önemli kararları mutlaka bir mahkemeye onaylatmalarının gerekli olmasıydı. Üstelik Batı Avrupa'daki uygulamaların aksine üyeler arasındaki anlaşmazlıklarda sorun lonca içinde değil, devlete danışılarak çözülmekteydi (Kuran, 1999: 106).

20. İslam hukuku seküler yasalara yer bırakmaksızın yaşamın tüm alanlarını düzenlemeyi amaçlamaktaydı. ilke olarak, islam hukukunun varsayılan kapsayıcılığı alt topluluklara özyönetim tanımaya elvermemekteydi. Sınırlı alanlarda dahi ilahi hukukun yerine insan yapımı hukuk geçirilemezdi (Kuran, 2018: 140).

21. Loncaların tekelci birimler olarak rekabeti engelleyici koşullarda faaliyette bulunmasında devletin tercih ve desteği şüphesiz önemlidir. Loncalar dükkân sayısını sınırladıklarında veya girdilerin dağıtımını düzenlediklerinde bu durum devletin çıkarları ile örtüşüyordu çünkü devlet bu sayede bir yandan kendi vergi tahsilâtını güvence altına almış oluyor, diğer yandan kendisi için tehdit oluşturabilecek büyük sermaye sahibi oluşumları engelliyordu (Kuran, 1999: 105).

22. İslam hukukunun mirasa yönelik hükümleri de ortaklıkların kurulması bakımından engelleyici bir rol oynamıştır. İslam hukukunda miras sistemi bir ortaklığın, ortaklardan birinin ölümü sebebiyle zamanından önce tasfiye edilmesinin maliyeti yükseltmesi niteliğiyle ortaklıkların çapını ve süresini sınırlandırmış, başarılı tüccarların terekelerinin parçalanmasına yol açmış ve işletmelerin kuşaklar boyunca faaliyetinin sürdürülmesine engel olmuştur. Bu durumda küçük ve kısa ömürlü ortaklıkların üyeleri karmaşık muhasebe yöntemleri geliştirme veya hisse alım-satımıyla daha büyük akışkanlık elde etmeye gerek görmemişledir. Standartlaştırılmış bir muhasebe sisteminin yokluğunda kâr amaçlı bir ortaklığın net değeri, yatırımcılara anlamlı gelecek biçimde ölçülememekte ve ayrıca iflas durumu ortaya çıktığında süreç ciddi anlaşmazlıkları ortaya çıkarmaktadır. Hisse alım-satımına dönük kurumsal bir altyapının yokluğunda, bir ortaklığa yatırım yapmak akışkanlıktan vazgeçmeyi gerektirmektedir. Sırf bu nedenlerden dolayı tüzel kişilik kazanmaya çalışan bir Orta Doğulu tüccarın sermaye bulmakta zorlanması kaçınılmaz olmuştur (Kuran, 2018: 163).

23. Osmanlı hukukunda ortaklık kurulmasına dair kural ve düzenlemeler akit şirketi başlığında ifade edilmiş olup akit şirketi (şirket-i akd) sermaye olarak mal (emvâl), emek (a'mâl) veya itibar (vücûh) ortaklığı altında üç şekilde kurulabilmekteydi. Söz konusu akit şirketleri de kendi aralarında mufâvada (eşitlik) ve inan şirketi olmak üzere ikiye ayrılıyordu. Sermaye ağırlıklı ticari şirketleri ifade etmek için kullanılan emvâl şirketi iki veya daha fazla kişinin elde edecekleri kârı belli oranda bölüşmek üzere sermayelerini birleştirerek kurdukları ticari ortaklığı ifade etmekteydi. Mufâvada şirketi sermaye ve tasarruf yetkisi bakımından eşit iki ya da daha fazla kişi arasında kurulan ve ortaklar arasında hem vekâlet hem kefalet ilişkisini gerektiren bir şirkettir. Eğer ortaklar aralarında şirket sermayesi, elde edilecek kazanç ve tasarruf yetkisi hususlarında tam bir eşitlik olmak şartı ile bir şirket kurmuş ve şirket sermayesi olabilecek bütün mallarını da bu şirkete dâhil etmişlerse, meydana gelen ortaklık eşitliğe dayalı olduğundan mufâvada olmaktaydı (Gedikli, 1999: 433).

24. Şirketlerin kurulmasına dönük teşvik amaçları arasında oluşacak güç birliği sayesinde ham madde ve makine ithalatını gerçekleştirme olanağı yaratmak, devlet gereksinimlerini kurulacak şirketlerden temin etmek ile çırak ve usta vb. yetişmiş iş gücü ihtiyacı için sanat okulları açmak bulunmaktadır (Koraltürk, 1999: 443-4).

25. Kurulan şirketlerin tamamına yakınının kurucuları ve yöneticileri Levantenlerden ve yabancılardan oluşmaktaydı. Müslüman sermaye sahiplerinin şirketleşmeye uzak bakmasındaki en önemli etken olarak şirketleşmenin hız kazandığı dönemde padişah olan II. Abdülhamid'in baskıcı yönetimi karşısındaki çekince ile yasal düzenlemelerin yetersizliği görülebilir. Osmanlı hukukunda tüzel kişilik kavramının yeterince tanımlanmamış olması ve ticaret eğitiminin yetersiz oluşu da diğer faktörler olarak değerlendirilebilir (Koraltürk, 1999: 444).

26. Tanzimat Fermanı'nın ilanını takiben Osmanlı yöneticileri ilk dönem modern imalat işletmelerinin kurulmasında Avrupalılara önemli bir rol vermişlerdi. Kapitülasyonlar devletin bu işletmelerin ürünlerini vergilendirmek için farklı muameleye tabi tutulmasını engellemesine rağmen, Avrupalı yatırımcılar ham madde bolluğu, potansiyel pazarın 
genişliği ve ucuz iş gücü sebebiyle yatırım yapmayı cazip bulmaktaydılar. Kurulan bazı bölgesel fabrikaların sahipleri de genellikle Avrupa korumasındaki gayrimüslimlerden oluşmaktaydı (Kuran, 1999: 108).

27. İlk anonim şirket olan Şirket-i Hayriye'nin kuruluşunda hisselerin satılmasındaki güçlük karşısında sadrazamın telkinlerine karşın satışların sadece elit bürokrat tabaka ve yakınları ile sınırlı kalmış olması, tasarruf sahiplerinin şirket hisselerinin satın alınmasına dönük bir alışkanlığının olmadığının bir göstergesi olarak kabul edilebilir (Koraltürk, 1999: 445).

28. Coase Kanununda ifade edildiği gibi kurumların "kendilerine ihtiyaç duyulduğunda" ortaya çıkmayıp Osmanlı imparatorluğu'nda devlet müdahalesi sonucu kurulmuş olmaları anonim şirketlerin Batı'dan farklı olarak sergiledikleri yönelmeyi açıklamada kullanılabilir (Çizakça, 1999: 183-184).

29. Balta Limanı Anlaşması'nın ithalatla ilgili maddesine göre ithal mallar \%5 ithalat resmi ödenmesi koşuluyla ülke içerisinde serbestçe pazarlanabilmekteydi. Oysa ülke içinde dolaşıma giren yerli malların bir yerden bir yere sevkiyatında âmediye, reftiye, müririye, masdariye gibi birçok resmin ödenmesi zorunluydu (Eşiyok, 2010: 88).

30. Sanayi Devrimi sonucunda gerçekleşen standart ve seri dokuma ürünleri üretimi Osmanlı imalat sektörünü 1838 Balta Limanı Anlaşması öncesinde etkilemeye başlamıştı. Hatta bir görüşe göre anlaşma yapılmamış olsa dahi Osmanlı imalat sektörü Sanayi Devrimi karşısında tutunamayacaktı. Hal ne olursa olsun anlaşmanın yürürlüğe girmesinin ardından ucuz ve kaliteli ingiliz pamuklularının neredeyse tüm Osmanlı pazarını istila etmiş olması, anlaşma ile Osmanlı ülkesinin makine kullanılarak üretilmiş Avrupa menşeli dokuma ürünlerinin bir açık pazarı haline geldiğinin bir kanıtı niteliğindedir (Eşiyok, 2010: 83-7).

31. Bursa ve civarındaki ipekli ve pamuklu dokumacılarının el tezgâhlarında ürettikleri toplam giysi sayılarındaki azalış da söz konusu gerileme sürecini teyit eder niteliktedir. Öyleki 1843 yılı itibarıyla bölgede el tezgâhı ile üretim yapan dokumacılar 20.000 parça giysi üretmekte iken bu sayı 1846'da 13.000'e, 1863'e gelindiğinde ise 3.000'e kadar düşmüştür (Quataert, 2011: 205).

32. Iplik fiyatlarında ithal iplik lehine oluşan bu durumun mekanizasyona dayalı üretim haricindeki diğer sebebi, 1838 Balta Limanı Anlaşması hükümlerinin yabancı tüccarlar lehine oluşturduğu maliyet farkından kaynaklanmaktadır. Öyleki Osmanlı sınırları içerisinde faaliyet gösteren bir yabancı tüccar bir defalığına ithal mala \%5 düzeyinde vergi ödediğinde malına herhangi bir iç tarife üzerinden vergi ödemeksizin ülke sınırları içinde pazarlama hakkına sahipti. Bununla birlikte anlaşma hükmü gereğince tüm yerel tüccarlar yerli mallara 21 no.lu dipnotta belirtilen vergileri ödemek durumundaydılar (Erder, 1976: 231).

33. Sanayisizleşme ile genellikle el tezgâhlarına dayalı üretim organizasyonlarında küçülme ve buna bağlı olarak mevcut iş gücünün atıl kalması ya da başka işlere yönelmesi kastedilmekle birlikte sanayisizleşmenin sebepleri ve sonuçları ülkelerin kendilerine özgü sosyoekonomik koşullara bağlı olarak farklılık göstermektedir. Sanayisizleşmeyi tarihsel süreç içerisinde "erken" (premature) ve "ileri" (advanced) sanayisizleşme olarak ele almak daha doğru görünmektedir. Zira erken sanayisizleşme Sanayi Devrimi sonrasında merkez ve çevre ülkeleri arasında gelişme gösteren uluslararası ticari iş bölümünün belirlediği ticaret hadlerinin sonucunda ortaya çıkan bir olgu iken ileri sanayisizleşme erken sanayisizleşmeden farklı olarak II. Dünya Savaşı sonrası sanayileşme çabasına giren Üçüncü Dünya ülkelerinin sanayileşme sürecindeki geri ve ileri bağlantıları üzerine odaklanmaktadır. Ayrıntılar için bk. Singh (1977) ve Bluestone ve Harrison (1982). Bu çalışmanın kapsamına giren erken sanayisizleşme süreci, Sanayi Devrimi ile Batı Avrupa'da makineli üretime geçişin bir sonucu olarak dokuma sektörü başta olmak üzere ucuz ve kaliteli mamul mallar üretiminin merkezden "çevre ülkelere" giderek artan oranlarda ürün satışı sonucunda ilave kâr düzeyinin yükselmesi ile başlamıştır. Merkez ülkelerin mamul mallardaki rekabet üstünlüğüne bağlı olarak ortaya çıkan bu süreç zorunlu olarak bir uluslararası iş bölümünün doğmasına yol açmıştır. Zira merkezden çevre ülkelere sürekli mamul mal ihracatı ancak çevreden yüksek kalitede ve ucuz ham madde temin edilmesine bağlıdır. Nitekim iktisadi ve siyasi sebeplere dayalı biçimde serbest dış ticaretin önündeki engellerin kalkmasıyla birlikte çevre ülkelerden merkeze ham madde ihracatı artış göstermiştir. Uzun dönemde dış ticaret hadlerinin mamul mallar lehine dönmesiyle birlikte merkez ve çevre ülkeler arasında bir eşitsiz değişim ilişkisi ortaya çıkmış ve birincil mal üreticisi sektörlerden merkezdeki yüksek teknolojili sanayilere artık transferi sistematik hale gelmiştir. Anlatılan eşitsiz değişim ilişkisi kapsamında çevre ülkelerde sürekli hale gelen mamul mal ithalatı ile birlikte çevredeki bu tür imalatlarda bir yandan mevcut imalatların ithal mallarla rekabet etme şansı ortadan kalkarken diğer yandan imalatlarda çalışan iş gücünün bir bölümü açığa çıkarak birincil mallar üretimine yönelmek durumunda kalmıştır (Teoman ve Bozpinar, 2020: 160-161).

34. Osmanlı iç ticaretinde bazı malların alım satımının sadece devlet tarafından belirlenmiş kişilerce yapılarak ülkeden ham madde çıkışının önlenmesine dönük olarak 1826 yılında uygulamaya koyulan tekelci uygulama (Önsoy, 1988: 14). 
35. Bu çalışmada XIX. yüzyıl Bursa ipek sektöründeki yapısal dönüşüm ile Avrupa ipekli dokuma sektörüne ham madde tedarikçiliğine geçiş süreci kozacılık temelinde değil, ham ipek ipliği üretimi temelinde incelenmiştir.

36. Fransa'nın Lyon şehrindeki St. Etienne bölgesi aynı Bursa'da olduğu gibi el tezgâhlarında dokumacılığın gelişmiş olduğu bir bölge idi. 1466'da Fransa Kralı XI. Louis'nin Lyon şehrini bir dokumacılık merkezi olarak seçmesiyle başlayan ipekli dokumacılıkta uzmanlaşma süreci, 1535 yılında Kral I. Francis'in iki italyan tüccara dış ticaret imtiyazı vermesi ve genç kızlara dokumacılık eğitimi verilmesine dönük bir okulun açılmasıyla hız kazanmıştır. 1540'ta ipek üretim tekelinin şehre verilmesi, şehrin kaderini değiştirmiştir. Öyleki Lyon 1620 yılına gelindiğinde Avrupa ipek sermayesinin başkenti olan Valencia'yı yakalamış ve şehirde 10.000'in üzerinde tezgâh çalışır hale gelmiştir. ipekli dokumada mekanizasyona geçiş ise Napolyon dönemine denk gelmektedir. Ingiltere ve İsviçre'deki makineli üretimin yaratmış olduğu rekabetin bir bakıma zorunlu kıldığı bu geçiş, 1801 yılında Joseph Marie Jaquard'ın icat ettiği günümüzdeki bilgisayarlı-kartlı sistemin basit bir benzeri olan mekanik tezgâhın kullanılmaya başlanması ile sağlanmıştır (Mooers, 1997: 105). Bu tip tezgâhın devreye girmesiyle ipekli dokumacılıkta üretim, verimlilik ve istihdam açısından dengeler değişmiş ve Bursa menşeli ipeğin işlenmesine dayalı Lyon ipeklilerinin dış piyasalardaki rekabet gücü artmıştır. Tarih boyunca benzer süreçlerden geçmelerine karşın, XIX. yüzyıldan itibaren Osmanlı ipekli dokumacılığı gerilerken Fransa'da makineli üretime dayalı dokuma sektörünün gelişmesinde Fransa'da kurumsallaşmış bir kredi piyasasının varlığı ve şirketleşme olgusu en önemli faktörler olarak değerlendirilebilir. Nitekim Fransa'nın sanayileşmede take-off (kalkış) aşamasını yakaladığı 1830 ve 1840'larda girişimciler çok sayıda commandite-sermaye ortaklığı tarzı organizasyonlara başvurmuşlardır. Fransa'da 1826'dan 1837'nin sonuna kadar sanayide toplam 1100 adet sermaye ortaklığı şeklinde kurulmuşşirket bulunuyorken 157 şirket anonim şirket olma hakkı elde etmiş olup toplu olarak değerlendirildiğinde bu kurumsal yapıların sanayileşme için gerekli sermayeyi seferber etme yeteneğine önemli ölçüde katkı sağladığı sonucuna ulaşılmaktadır (Cameron, 1967: 108-9).

37. Bursa ve civarında evlerde gerçekleştirilen fason imalat konusunda 1830'ların başında bir gezginin gözlemleri fikir verici niteliktedir. Gezgin, bölgede en fazla iki tezgâhın sığabileceği kadar küçük hanelerde zor koşullarda ipek imalatı yapıldığını ifade etmektedir (Erder, 1976: 98-9). Bölgedeki farklı üretim biçimlerinin varlığı konusunda H. Gerber, herhangi bir lonca ile bağlantılı olmayıp, fason üretim dışında kalarak bağımsız olarak üretim faaliyetlerini sürdüren bireysel zanaatkârların da göz ardı edilemeyecek düzeyde olduğunu iddia etmektedir (Gerber, 1988: 53).

38. Osmanlı loncaları, bir malın üretiminde uzmanlaşmış olup olmadığı fark etmeksizin, ülkenin çoğu şehrinde ihtiyaç duydukları ham maddeyi devlet organlarından istedikleri düzeyde temin eden tek kurumdu. Bursa'daki üretim ilişkilerinin katı lonca kurallarının dışına çıkılabilen nitelikteki göreli olarak esnek yapısı tüccarlara üretim sürecine doğrudan dâhil olarak sermaye birikimlerini artırabilmelerinin önünü açmış ve tüccarlar bu birikimi ipek çekiminin makineyle yapıldığı imalathanelerin kurulmasında kullanabilmişlerdir (Yıldırım, 1999/2000: 157).

39. ipek ipliğinin çekilmesinde kullanılan makine mancınık ya da filatür olarak adlandırıldığından ipek fabrikalarına mancınıkhane ya da filatür denilmiştir. Ayak gücüyle çalıştırılan mancınık tepme mancınık olarak adlandırılırken 1840'dan itibaren açılan fabrikalarda buharlı mancınıklar devreye girmiştir (Baskıcı, 2005: 194-5, dipnot 92).

40. Bursa ve yöresinde faaliyet gösteren filatür tesislerinde üretilen ipek ipliğinin yerel tüketim dışında kalan kısmının 4/5'i Fransa'ya, geri kalanı ise ingiltere'ye gönderilmekteydi (Yılmaz, 2019: 105).

41. Bursa'da buhar gücüyle çalışan makinelerde iplik çekimi yapan ilk filatür tesisi 1838'de koza ve ipek ticareti ile uğraşmakta olan Ermeni Ohannes Taşçiyan, Bayaoğlu Osep Ağa ve Falkheisen ortaklığı sonucunda kurulmuştur. Bu fabrikanın 1839'da yanması sonucunda Falkheisen "Henry et Daniel Muraltfiles et Cie" isimli bir isviçre firması ile ortaklık kurarak 1845 yılında ikinci fabrikasını kurmuştur. Ardından Ermeni Boğos ve damadı Agop Düzoğlu italya'dan getirttikleri ve yaklaşık 750 çıkrıklı filatür tesisini kurmuşlardır. Bursa'da 1850'den sonra filatür tesisi sayısı hızla artmış, 1851'de 5 olan tesis sayısı 1855'te 23'e, 1856 yılında ise 45'e çıkmıştır (Yılmaz, 2019: 71). Zaman içinde bazılarının kapanmasına karşın Osmanlı Imparatorluğu'na ilişkin 1913 ve 1915 yıllarına ait sanayi istatistiğinde Bursa ve civarında 41 filatür tesisi bulunduğu rapor edilmiştir (Ökçün, 1984: 140-2). ilk filatür tesislerine ilişkin olarak ayrıca bk. Dalsar (1960).

42. Bakterinin yol açmış olduğu üretim düşüşlerinin önüne geçebilmek amacıyla 1864 yılından itibaren Japonya'dan sağlıklı ipek böceği yumurtası ithaline başlanmış olmasına karşın, ithal edilen kozaların nispeten küçük olması sebebiyle üretim düzeyinde arzu edilen üretim artışları gerçekleştirilememiştir (Quataert, 2011: 223).

43. Bursa merkezi dışında Yenişehir, Gemlik, Karacabey ve Bandırma ilçeleri ile Bilecik'te de filatür tesisleri kuran Agop Düzoğlu isimli girişimcinin yalnızca Bursa'daki tesisinde 150 kadın iş̧̧inin çalışmakta oluşu, bölgede ücretli işgücü istihdamı açısından kapitalist üretim koşullarının geçerli olduğunun bir kanıtı olarak kabul edilebilir (Erder, 1976: 102). Yine bir başka çalışmada 1850'li yılların ortasında Bursa vilayetindeki filatür tesislerinde çalışan işçi sayısının 3800'e ulaşmış olduğu belirtilmektedir (Yılmaz, 2019: 93). 
44. Quataert (2011: 236-7)'a göre Bursa vilayetinde koza hasadı dönemi 20 Haziran ile 20 Temmuz arasındaydı. Aktar (2006: 215)'a göre ise koza alımları Ağustos ve Eylül aylarında yapılmakta olup filatür tesislerinin bir sezon işleyecekleri tüm yaş kozayı aynı anda satın almaları gerekiyordu. Aksi takdirde kozanın içindeki kelebeğin kozayı delip uçmasıyla koza zarar görmekteydi.

45. Bu konuda 1838 Balta Limanı Anlaşması ile serbest ticaret kuralları geçerli olmaya başladığında Sultan III. Selim döneminde "Avrupalı Tüccarlar" ile eşit koşulda ticaret yapabilme olanağına kavuşan Müslüman "Hayriye Tüccarları"nın ülke genelinde rekabet güçlerini kaybettikleri ileri sürülmektedir (Bağış, 1983: 99). Erder (1976: 103-4) ise bölgede gayri resmi kredi piyasasında geçerli olan yıllık borçlanma faiz haddinin \%20 ila \%40 arasında değiştiğini belirtmektedir. Bölgedeki dokumacı ve çekimci zanaatkârların böylesi yüksek faiz oranlarından borçlanarak yatırıma girişmelerinin oldukça riskli ve caydırıc nitelikte olduğu savunulabilir.

46. Osmanlı mali düzeninde XVI. yüzyılda başlayan askeri, iktisadi, siyasi ve demografik sebeplerden kaynaklı mali bunalım, Avrupa menşeli "Fiyat Devrimi"nin etkileri ile derinleşmiş, bunalıma iç borçlanma çare olamayınca Kırım Savaşı (1854-1855) sonrasında dış borçlanmaya gidilmek durumunda kalınmıştır. Ayrıntılar için bk. Pamuk (2005).

47. Cezayirliyan Tanzimat Fermanı'nın mimarlarından olan Sadrazam Mustafa Reşit Paşanın da sarrafı olup askeri ve sivil bürokrasi ile yakın maddi ilişkiler kurmuş bir kişi idi (Manav, 2019: 45).

48. Sarrafların bir kısmı bireysel olarak iltizam ihalelerine girmeksizin bir başkasını finanse etmek suretiyle kârdan pay alma yöntemini tercih etmekte idiler. Buna göre mültezimler devlete verecekleri teminatları genellikle sarraflardan sağlıyor, sarraflar da mültezimlerin kârlarına ortak oluyorlardı (Daşdemir, 1999: 476).

49. Ijpek çekiminin yanı sıra fabrika kurulmasına dair benzer uygulamalar ipekle ilgili diğer sektörlerde de gözlenmektedir. Örneğin harir fabrikasının kurucusu, 1842 yılı Tırhala Sancağının harir öşürünün toplanması için mültezim olarak görevlendirilmesi koşuluyla bu fabrikayı kurmaya talip olduğunu bildirmiş ve bu özel şart devletçe kabul edilmiştir. Ayrıca Tırhala Sancağı bölgesinde kurulacak sabun fabrikasının ürettiği sabundan adı geçen bölge içinde gümrük resmi de alınmayacağı hükme bağlanmıştı (Kala, 1999: 287-8).

50. Osmanlı Imparatorluğu'nda neredeyse her paşanın bir sarrafı vardı. Örneğin Koca Ragıp Paşa'nın sarrafları Bedros ve Kazaz'dı. Sadrazam Melek Ahmed Paşa'nın sarrafı, Diyarbakırlı Mağakya Çelebi, Çıplak Hüseyin Paşanınki sarraf Dares idi (Manav, 2019: 27-28).

51. Fabrikanın kuruluş amacının ipekböceği kozalarının üreticiden ucuza alınarak ham ipek imalatında tasarruf sağlanması olduğu ifade edilmiştir (Yılmaz, 2019: 71).

52. Diğer taraftan Osmanlı Imparatorluğunda Osmanlı zihniyeti dışına çıkıldığında sanayi kurulabileceğinin ve bunun başarılı olacağının tipik örneği Mehmet Ali Paşa'nın Mısır'daki girişimidir. Ayrıntılar için bk. Teoman ve Kaymak (2010), Marsot (2010) ve Özkoç (2014).

53. Fabrika her ne kadar devletin ipek işleme tesislerinin gözdesi konumunda olsa da Sarım Paşanın buhar gücüyle çalışan iki fabrikasıyla mukayese edilemezdi. Devlet fabrikasının cirosu 1860'ların başında yaklaşık olarak 180.000 Fransız Frangı düzeyinde iken Sarım Paşanınki yaklaşık beş katı olan 920.000 Frank düzeyinde idi (Erder, 1976: 109).

54. XIX. yüzyılın başında Osmanlı Imparatorluğu gibi Japonya da bir çevre ülkesi olup kurumsal yapısı da benzer şekilde Batı'daki kurumsal dönüşümü gerçekleştirmede yapısal direnç özelliklerine sahiptir. Söz konusu ortak özelliklere karşın Japonya bu çalışmanın konusunu teşkil eden ipekli sektöründe devlet desteği ve teşvikiyle Batılı ülke deneyimlerinden farklı bir biçimde sanayileşmeyi başarabilmiş ve XX. yüzyılın başında dünya pazarlarına hâkim olmuştur. Osmanlı ve Japonya'nın ipekli sektöründeki sanayileşme deneyimlerinin karşılaştırmasını konu alan bir çalışma için bk. Teoman ve Bozpinar (2020).

55. Nitekim 1913 ve 1915 yıllarına ilişkin Osmanlı sanayi istatistikleri XX. yüzyılın başında filatür tesislerinin çoğunluğunun sahipleri tarafından işletilmeyip kiraya verildiğini, hatta çeşitli mevsimlerde sahibinin/kiracısının değiştiğini ortaya koymaktadır (Ökçün, 1984: 140-2).

56. I. Meşrutiyetin ilanını takiben Osmanlı Imparatorluğu’ndaki siyasi dönüşüm süreci ve etkileri için bk. Mardin (1995).

\section{Kaynaklar}

Akbaş, H. E., Bozkurt, S., \& Yazıcı, K. (2018). Osmanlı Devleti'nde lonca teşkilatı yapısı ve yönetim düşüncesi ile karşılaştırılması. Muhasebe ve Finans Tarihi Araştırmaları Dergisi, Özel Sayı, 165-202.

Aktar, A. (2006). Türk milliyetçiliği, gayrimüslimler ve ekonomik dönüşüm. İstanbul: İletişim Yayınları.

Bağış, A. İ. (1983). Osmanlı ticaretinde gayri Müslimler. Ankara: Turhan Kitabevi.

Baskıcı, M. M. (2005). 1800-1914 yıllarında Anadolu'da iktisadi değişim (1. baskı). Ankara: Turhan Kitabevi. 
Bluestone, B., \& Harrison, B. (1982). The deindustrialization of America: Plantclosings, community abandonment, and the dismantling of basic industry. New York: Basic Books.

Bozpinar, C. (2020). Weberyan subjektif rasyonalite: Osmanlı iktisadi zihniyeti. Efil Journal, 3(9), 126-45.

Cameron, R. E. (1967). Banking in the early stages of industrialization: A study in comparative economic history. New York: Oxford Univ.

Cipolla, C. M. (2005). Before the Industrial Revolution, European society and economy 1000-1700 (3rd ed.). London: Routledge Press.

Çizakça, M. (1999). İslam dünyasında ve Batı'da iş ortaklıkları tarihi. İstanbul: Tarih Vakfı Yurt Yayınları.

Çizakça, M. (2004). Osmanlı cash waqfs revisited: The case of Bursa 1555-1823. FSTC Limited.

Dalsar, F. (1960). Türk sanayi ve ticaret tarihinde Bursa'da ipekçilik. İstanbul: İstanbul Üniversitesi Yayınları.

Daşdemir, L. (1999). Osmanlı Devleti'nde banker-sarraf faaliyetleri yahut bir gerileme sebebi olarak bankacılıktaki gelişme. (Ed.) G. Eren, Osmanlı (Cilt 3). Ankara: Türkiye Yayınları.

Erder, L. T. (1976). The making of industrial Bursa: Economic activity and population in a Turkish city: 1835-1975 Princeton University, Unpublished PhD Thesis.

Eşiyok, A. B. (2010). Osmanlı İmparatorluğu’nun dünya ekonomisine eklemlenmesinde bir dönüm noktası: 1838 Serbest Ticaret Antlaşması. Mülkiye Dergisi, 266(34), 67-108.

Fleet, K. (1999). Osmanlı topraklarında Latin ticareti (XIV-XV. Yüzyıllar). (Ed.) G. Eren, Osmanlı (Cilt 3). Ankara: Türkiye Yayınları.

Gedikli, G. (1999). Osmanlı şirketleri. (Ed.) G. Eren, Osmanlı (Cilt 3). Ankara: Türkiye Yayınları.

Genç, M. (2012). Osmanlı iktisadi dünya görüşünün ilkeleri. İçinde Osmanlı Imparatorluğunda devlet ve ekonomi (ss.4569). İstanbul: Ötüken Neşriyat.

Genç, S. Y., \& Ekiz, R. (2017). Kurumsal iktisadi düşüncenin terminolojik ve metodolojik bir incelemesi. (Eds) K. Çolak, S. Koç \& S. Y. Genç, Dünden bugüne ekonomi yazıları. Küv Yayınları.

Gerber, H. (1988). Guilds in Seventeenth Century Anatolian Bursa. Asian and African Studies, 11, 59-86.

Godelier, M. (1978). Infrastructures, societies and history. Current Anthropolgy, 4(19), 763-71.

Gündoğdu, U. (2019). 19. yüzyıl Osmanlı İmparatorluğu'nda kırsal borçluluk bağlamında emek ve mülkiyet ilişkilerinin dönüşümü. Ege Üniversitesi Sosyal Bilimler Enstitüsü, Yayımlanmış Yüksek Lisans Tezi, İzmir.

Hadden, T. (1972). Company law and capitalism. London: Weidenfeld \& Nicolson.

Hayek, F. A. (1998). Law, legislation and liberty. London: Routledge \& Kegan Paul Ltd.

Kağıtçıbaşı, E., \& Yaşar, E. (t.y.). Bursa'nın ekonomik tarihi: 1326-1900. Bursa Sanayi ve Ticaret Odası.

Kala, A. (1999). Osmanlı Devleti'nde sanayileşmenin ilk yıllarında özel fabrikalar. (Ed.) G. Eren, Osmanlı (Cilt 3). Ankara: Türkiye Yayınları.

Kama, Ö. (2011). Yeni kurumsal iktisat okulunun temelleri. Gazi Üniversitesi Iktisadi ve Idari Bilimler Fakültesi Dergisi, 13(2), 183-204.

Kazgan, H. (1999). Osmanlı'dan Cumhuriyet'e şirketleşme. İstanbul: Creative Yayıncılık.

Kazgan, H. (2005). Galata bankerleri (Cilt 1). Ankara: Orion Yayınevi.

Keyder, Ç. (1999). Osmanlı İmparatorluğu'nda XVIII. ve XIX. yüzyıllarda imalat sanayii. (Ed.) G. Eren, Osmanlı (Cilt 3). Ankara: Türkiye Yayınları.

Koraltürk, M. (1999). Osmanlı Devleti'nde şirketleşme, ilk anonim şirket ve borsanın kuruluşu. (Ed.) G. Eren, Osmanlı (Cilt 3). Ankara: Türkiye Yayınları.

Koyuncu, N. (2018). Osmanlı Devleti'nde esnaf gediklerinin hukuki esasları, gelişimi ve ilgası. Selçuk Üniversitesi Hukuk Fakültesi Dergisi, 26, 47-76.

Kuran, T. (1999). Osmanlı lonca teşkilatı üzerine İslami etkiler. (Ed.) G. Eren, Osmanlı (Cilt 3). Ankara: Türkiye Yayınları.

Kuran, T. (2018). Yollar ayrılırken: Ortadoğu'nun geri kalma sürecinde íslam hukukunun rolü (2. baskı). İstanbul: Yapı Kredi Yayınları.

Küçükkalay, M. (2001). Coğrafi keşifler ve ekonomiler Avrupa ve Osmanlı Devleti. Konya: Çizgi Kitabevi Yayınları.

Manav, N. (2019). Zenginlikten iflasa-Mustafa Reşit Paşa'nın sarrafı Cezayirlioğlu Mıgırdiç. İstanbul: LiBRA Kitap.

Mardin, Ş. (1995). Türk modernleşmesi. İstanbul: İletişim Yayınları. 
Marsot, A. L. A. (2010). Mısır tarihi: Arapların fethinden bugüne (1. baskı). (Çev. G. Ç. Güven). İstanbul: Tarih Vakfı Yurt Yayınları.

Marx, K. (1997). Kapital (Cilt 3). (Çev. A. Bilgi). Ankara: Sol Yayınları.

Marx, K. (2011). Ekonomi politiğin eleştirisine katkı. (Çev. S. Belli). Ankara: Sol Yayınları.

Mooers, C. (1997). Burjuva Avrupa'nın kuruluşu. Ankara: Dost Kitabevi.

Neal, L., \& Cameron, R. E. (2016). A concise economic history of the World (5th ed.). New York: Oxford University Press. Ökçün, G. (1984). Osmanlı sanayii 1913-1915 istatistikleri. İstanbul: Hil Yayın.

Önsoy, R. (1988). Tanzimat Dönemi Osmanlı sanayii ve sanayileşme politikası. İstanbul: Türkiye İş Bankası Kültür Yayınları.

Özel, H. (2015). Piyasa sisteminin dinamizmi ve istikrarsızlığı: Weber ve Schumpeter. Iktisat ve Toplum, 61, 37-44.

Özkoç, Ö. (2014). Mısır modernleşmesinin tarihsel kökenleri: Mehmet Ali Paşa dönemi üzerine bir inceleme. Memleket Siyaset Yönetim, 21, 219-50.

Özsu, A. C. (2018). Osmanlı ve cumhuriyet modernleşmesinde gayrimüslim sanatçılar Hacettepe Üniversitesi Sosyal Bilimler Enstitüsü, Yayımlanmış Yüksek Lisans Tezi, Ankara.

Pamuk, Ş. (2005). Osmanlı-Türkiye iktisadi tarihi 1500-1914. İstanbul: İletişim.

Quataert, D. (2011). Sanayi Devrimi çağında Osmanlı imalat sektörü. (Çev. T. Gülsoy). İstanbul: illetişim Yayınları.

Seçilmiş, E. (2016). Coase Teoremine alternatif bir bakış. Finans-Politik ve Ekonomik Yorumlar Dergisi, 53(612), 9-20.

Shearmur, J. (1996). Hayek and After. London \& New York: Routledge Press.

Singh, A. (1977). Industry and the world economy: A case of de-industrialization? Cambridge Journal of Economics, 2(1), 111-36.

Smith, C. F. (1929). The early history of the London Stock Exchange. The American Economic Review, 19(2), 206-16.

Teoman, Ö., \& Bozpinar, C. (2020). XIX. yüzyılda Osmanlı İmparatorluğu ve Japonya'da sanayisizleşme: İpekli imalatı üzerine karşılaştırmalı bir değerlendirme. Marmara Üniversitesi Iktisadi ve Idari Bilimler Dergisi, 42(1), 157-79.

Teoman, Ö., \& Kaymak, M. (2010). 19. yüzyılda Osmanlı'da ticari tarım: Batı Anadolu ve Mısır'da pamuk üretimi merkezli bir karşılaştırma. İçinde Birinci iktisat Tarihi Kongresi tebliğleri (ss. 435-50). İstanbul: İstanbul Ticaret Odası Yayınları.

Walker, C. E. (1931). The history of the Joint Stock Company. The Accounting Review, 30(2), 97-105.

Wallerstein, I. (2004). Modern dünya sistemi. (Çev. L. Boyacı). İstanbul: Bakış.

Weber, M. (2012). Ekonomi ve toplum I. (Çev. L. Boyacı). İstanbul: Yarın Yayınları.

Yıldırım, O. (1999/2000). Osmanlı esnafında uyum ve dönüşüm: 1650-1826. Toplum ve Bilim, (83), 146-78.

Yılmaz, M. (2019). Bursa'da ipekböcekçiliğinin ekonomik coğrafya açısından etkileri: 1840-1920 (Yayımlanmış yüksek lisans tezi). Karabük Üniversitesi Sosyal Bilimler Enstitüsü, Karabük.

Yülek, M. (2019). Ulusların yükselişi. İstanbul: Kronik Kitap. 
This Page Intentionally Left Blank 